Historic, Archive Document

Do not assume content reflects current scientific knowledge, policies, or practices. 

$6 \% .09$

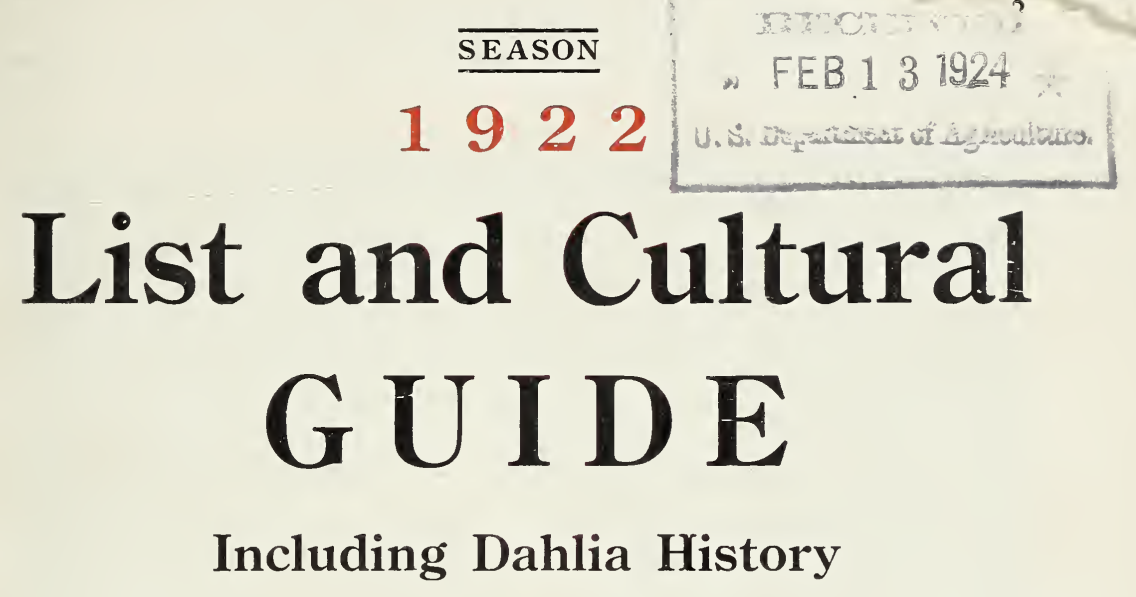

THE MOST FASCINATING PART OF
DAHLIA CULTURE IS FOUND IN ITS CONSTANT CHANGE OF TYPE AS NEW VARIETIES APPEAR. IT IS THE FLOWER OF SURPRISES-VIGOROUS, GORGEOUS, BRAZEN, BRAVE AND BEAUTIFUL, RESPONDING TO EACH KINDLY TOUCH IN GRATI. TUDE A HUNDRED FOLD

\section{- iof}

We are Members of

THE DAHLIA SOCIETY OF CALIFORNIA THE AMERICAN DAHLIA SOCIETY OF NEW YORK CITY

\section{LESLIE E. DOOLITTLE'S
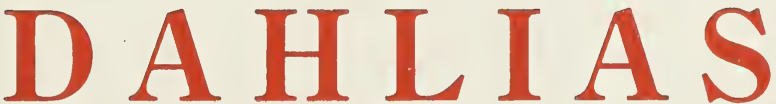

DEL MONTE, CALIFORNIA 


\section{GREETING}

\section{TO MY PATRONS AND FRIENDS:}

In issuing this, my twelfth ammual Dahlia Catalogue, I wish to again thank you for past favors, and to assure you that furtier favors will receive the same careful attention that we have always enjoyed showing our customers.

My intentions are to serve my customers a bit better than 1 would myself, be served.

The quality of tubers which I send out, including workmanship on same, is a revelation to the trade, in cleanliness of the tubers, the freeness from "scab" and other diseases.

We carefully weed out all poor or stunted plants, and greatly improve our stock by selection, each season, always planting the best stock of each variety, thus enabling us to supply better stock to eur customers, each season.

As we can now look back a few years and note the wonderful improvement and progress made in Dahlia culture, in California especially, we feel greatly rewarded for having spent at least a number of the best years of our lives, in growing Dahlias. Not witiout a great deal of joy and satisfaction do we also look into the future, a short way, and see some wonderful creations already unfolded to view, only waiting to become established varieties, which means that we cannot put a variety on the market until it has been grown at least three years. Up to three years time the changes taking place in the seedling are often very great.

We like to hear from our customers, of their successes, and to offer any possible help where complete success may not have been attained.

Wishing much joy to Dahlia lovers, one and all, I am Very sincerely yours,

LESLIE E. DOOLITTLE.

\section{IF YOU DON'T TRADE WITH US, WE BOTH LOSE}

A man in Oakland, Calif., writes us: Am unable to secure rcliable tubers locally. My only regret is that I did not learn of you and your wonderful Dahlias sooner. Please send me your latest Catalogue. 


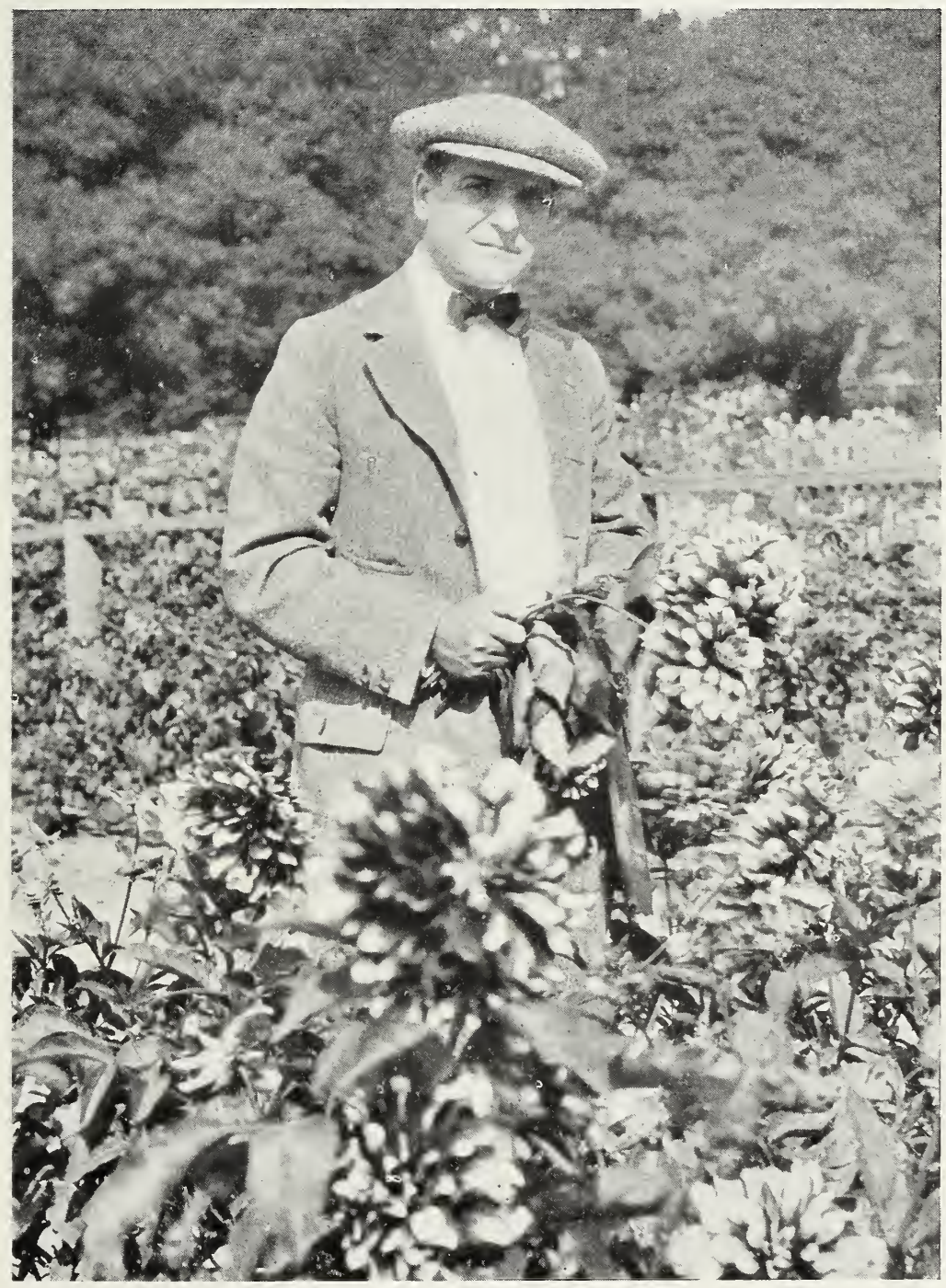

MR. EARL WILLIAMS AT DEL, MONTE

THE WELL KNOWN MOVIE STAR INSPECTING OUR "EARL WILLIAMS" DAHLIA, THE BEST VARIEGATED DAHLIA IN EXISTANCE-TODAY 


\section{VARIETIES of DAHLIAS}

In listing the different Dahlias, we have thought best to list them alphabetically, so the different types of blooms will be designated in this manner: The abbreviation "Dec." will signify the type known as "Decorative"; the "Peony" flowering type wi!l be marked with the letter P; the "Cactus", C, and "Show", S. The "Collarettes" and "Pompon" types will be found on Page 28. Where the variety we are describing favors two different types, both types will be mentioned. Varieties originated or named by myself will be marked "L. E. D."

Arguella-P. A new shade of deepest rose, with a deeper shade of what might be termed old Burgundy, suffused throughout the bloom. A very splendid new variety. An L. E. D. Introduction. Tubers, each $\$ 5.00$.

Attraction-P. Slightly on the "Cactus" type. Orchid to lavender pink. Delicate and beautiful. Tubers, each \$1.00.

Anticipation-Dec. A new Giant flowering Dahlia. Unique blooms. The color is salmon pink with light yellow shadings, sometimes marked with white. Upright growth. A fine exhibition variety. L. E. D. Tubers, each $\$ 10.00$.

Alvesia-P. A large soft pink, with a lavender tinge. L. E. D. Tubers, each $\$ 1.00$.

Autumn Tints-P. Has all the deeper tints of Autumn leaves. Medium sized bloom, broad petals with prominent center. L. E. D. Tubers, each $\$ 1.00$.

Audrey Varnell-P. Quite double, large, and of a new shade of deep orange. L. E. D. Tubers, each $\$ 1.00$.

Alsiska-P. One of the best pure white Dahlias in this type. Broad petaled, free flowering, and with good stem. Tubers, each $75 \mathrm{c}$.

Barioara Latz-P. This variety is among my best introductions. Being very large and free in bloom, it is very showy in its soft lemon yellow tones. Upright stem. L. E. D. Tubers, each $\$ 2.50$.

Button Bright of $\mathbf{O z}-\mathrm{P}$. A splendid new snow white Dahlia. L. E. D. Tubers, each $\$ 1.00$.

B. T. Dennes-P. A monarch among Dahlias. Deepest cherry and mahogany shades, with two to three rows of petals, beautifully curved. The stock of this variety is very limited, and if desired, should be ordered early. Tubers, each $\$ 1.00$. L. E. D. 
Byron-Dec. This does as well in our gardens as most any Dahlia we have, and we consider it one of the finest in existence. Of immense size and great depth. The petals are beautifully quilled, and are of a rich, deep wine color. L. E. D. Tubers, each $75 \mathrm{c}$.

Compensation-Dec.C. Brilliant cerise to claret wine color. Of great size and with splendid stem. One of the most desirable. L. E. D. Tubers, each $\$ 3.00$.

Constance-P. Giant star shaped flowers on good stem. A new and startling combination shade of cerise and carmine. An unusually bright flower. L. E. D. Tubers, each $\$ 2.50$.

Cheerfulness-P. Bright deep cherry red, of spiendid form. Tubers, each $75 \mathrm{c}$.

Creel's White-P. A pleasing shade of creamy white. Tubers, each $50 \mathrm{c}$.

Clara Seaton-Show. With possibly one exception (Golden Opportunity) this is the finest Dahlia of this type. The color is of a rich golden bronze, the petals being beautifully quilled. Reported to us as being the best in its color, of any Dahlia on the New York City market. L. E. D. Tubers, each 75e.

Claret Beauty-Dec. Deep claret wine color. Tubers, each $\$ 1.00$. Claret Cup-P. Rich claret wine color. Very free in bloom. Tubers, each 50c.

Creamo-Dec.-P. A Dahlia of much merit. A large light creamy yellow bloom, on extra stout stem. A splendid cut flower variety. L. E. D. Tubers, each 75c; 1 dozen tubers, $\$ 7.50$.

Cadiz-Dec.-C. A "sport" from the well known "Kalif". It is about the same form as the latter variety, but of a light orange color. Tubers, each $\$ 1.00$.

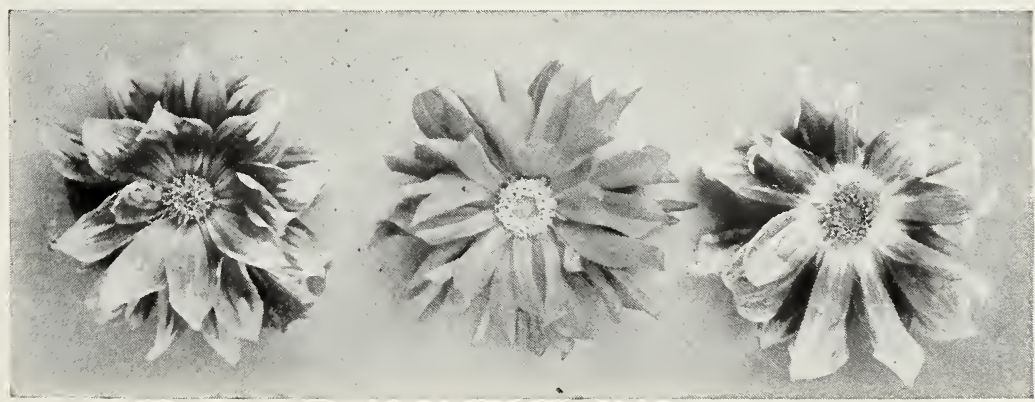


Claremont-P. A Carl Salbach introduction. A huge bloom that has been much admired in our garden. The colcr is a soft peach pink, with amber suffusion. Tubers, each $\$ 2.50$.

Copper-P. This has been one of our best Dahlias for garder show, for twelve years, and does well everywhere. Broad fluify petals of bronze and copper shades, with, at times, a suggestion of apricot pink. L. E. D. Tubers, each $\$ 1.00$.

Chowchilla-P. An musual and striking shade of warm yellow. L. E. D. Tuber's, each $\$ 1.00$.

City of Washington-Dec. C. A large bloom of snow white. Very good. Tubers, each $\$ 2.00$.

City of Portland-P. A giant flowering Dahlia from Oregon. Clear canary yellow. Tubers, each $\$ 4.00$.

C. C. Moore - P. This is one of the very fine California introductions. It is thrown out from the plant on great long stems. A pleasing shade of orange buff. Tubers, each $\$ 1.00$.

Col. Roosevelt-Dec. A large flowering purplish red. Tubers, each 50c.

Crystal-C. Soft, silvery pink. Petals somewhat incurved. Tubers, each $75 \mathrm{c}$.

Conquest-C. An incurved petal flower of much merit. Rich maroon. Tubers, each 75c. See similar type, No. 19.

Cole Hewins-P. Large, coppery yellow, with bronze shadings towards edges of petals. Tubers, each $\$ 1.50$. L. E. D.

Carary Cottage-P. Clear canary yellow, with beautifully quilled or fluted petals. L. E. D. 1920 introduction. Tubers, each $\$ 1.50$.

Cardoza-P. Deep violet purple. Good size. L. E. D. 1920 introduction. Tubers, each $\$ 1.00$.
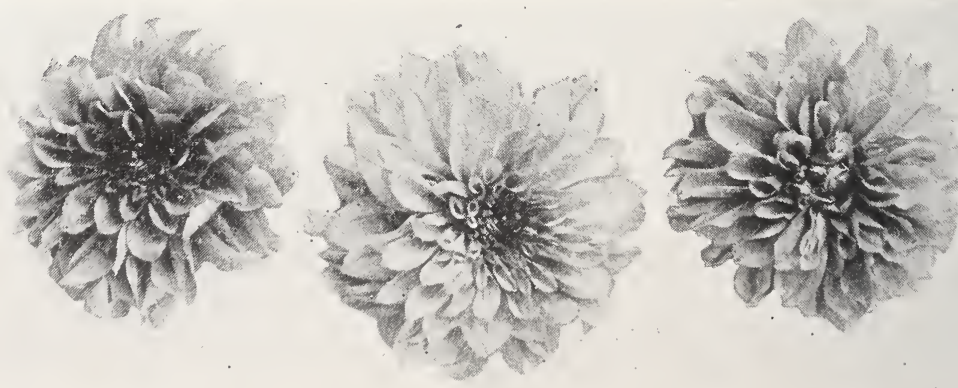
Ceylon-P. Buff color, with autumn tints. Very free flowering. Would be especially good for artistic decoration. L. E. D. 1920 introduction. Tubers, each $75 \mathrm{c}$.

Chatenay-P. A very modest flower of almost single form, extra strong stem. Color, apricot pink. Tubers, each 50e.

Cream King-P. A flower of immense size and of which our stock is especially good. Semi-double flowering, while the color is of a delicate, light lemon yellow. Tubers, each $\$ 1.00$.

Dream-P. A dainty flower of medium size, on upright stem. Delicate apricot pink shades. Tubers, each $\$ 1.00$.

Dr. Edwin Kertlan-P. A large attractive flower on good stem. The color is cerise to plum. L. E. D. Tubers, each $\$ 1.50$.

Dorothy Frances Peacock-P. White, shaded heavily with carmine rose. Stock of this variety very limited. L. E. D. Tubers, each $\$ 2.50$.

Doazon-Dec. A much improved "Sov. Doazon", this variety throwing blooms of mammoth size which are often too heavy for the fairly strong stem. Orange red shading to burnt orange toward the center. Tubers, each $50 \mathrm{c}$.

Delice-Dec. This has been considered one of the best Dahlias for fiorist use, as it has a splendid stem and good keeping quality. We recommend it for hedges and yard effect. It is a bright yet soft pink, and very free in bloom. Tubers, each $25 \mathrm{c}$.

Dr. H. L. Tevis-Dec. A very fine variety ; flowers 9 to 11 inches in diameter, erect on long. vigorous stem; color a beautiful shade of salmon rose, suffused gold and apricot. Tubers, each $\$ 1.00$.

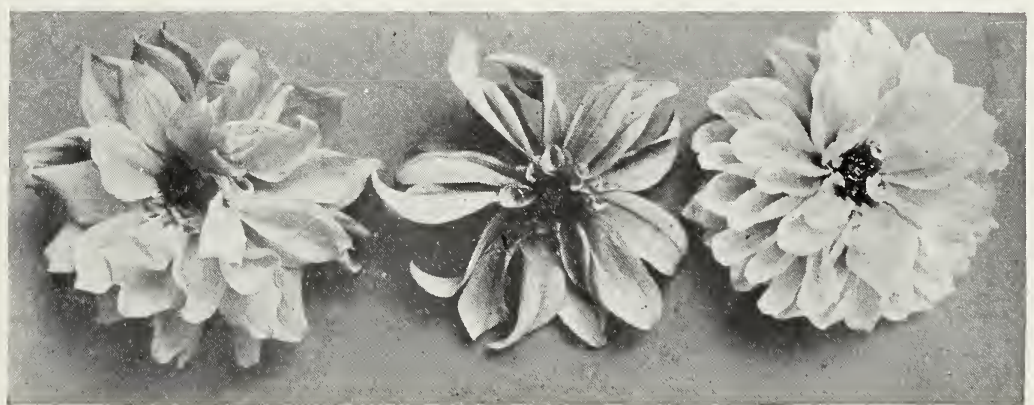


D Annunzio-P. A very large Duplex or Peony flowering Dahlia. Very free in bloom. Cerise to magenta. L. E. D. Tubel's, each $\$ 1.00$.

D. J. Desmond-P. White, suffused rosy lilac. Long, slightly incurved petals, of which there is but one row. Tubers, each $\$ 2.50$.

Electric-C. A very distinct variety. Incurved petals, bright golden yellow, tipped with white. Tubers, each $50 \mathrm{c}$.

Empress-C. Lilac pink, of large size and great beauty. Tubers, each $75 \mathrm{c}$.

Escalon-P. Quite double blooms, of richest bright crimson. Very free in bloom. and on excellent stems. One of the new winners. L. E. D. Tubers, each $\$ 5.00$.

Elko-P. Another splendid introduction. Red, each petal tipped gold. A most excellent value. L. E. D. Tubers, each $\$ 1.00$.

Ethel Compton-Dec. A large bloom of hydrangea pink. L. E. D. Tubers, each $75 \mathrm{c}$.

Eisanore-P. Medium sized flower. Very free in bloom. Deepest maroon. L. E. D. Tubers, each $75 \mathrm{c}$.

Earle Williams-Dec. So named after the movie star. This is a giant flowering Dahlia, we having grown it as large as 12 inches in diameier. The colors of brilliant crimson and white are well distributed. Plants are very free in bloom. This is one of the finest and most attractive Dahlias ever introduced. Similar form to No. 15 . L. E. D. Tubers, each $\$ 10.00$.

Ella Naomi Pierce-Double P. Giant flowering variety. The color is a "Du Barry" red, overlaid with blue flame. Wonderful. Words cannot describe its beauty. Tubers, each $\$ 2.50$. L. E. D.

Fancy Free-P. One of the most showy Dahlias. A bright shade of violet to roselake. Being very free in bloom, it is fine for hedge, or garden effect. L. E. D. Tubers, each $50 \mathrm{c} ; 1$ dozen for $\$ 5.00$.

Fascination-C. Delicate shell pink, shading to white at center. Long incurved petals of beautiful formation. Tubers, each $\$ 1.00$.

F. W. Fellows-C. A rich, orange-colored blossom of large size, with sharp-pointed petals. Very fine. Tubers, each $\$ 1.00$. Geo. Walters-Dec.-P. Another large flowering Dahlia with extra strong stems. Color, salmon and shrimp pink shades. Tubers, each $\$ 1.00$. 
Geisha-P. One of the most attractive Dahlias in exictence. Its form is most original; the petals showing more twists and curls than any other sort. The color is orange scarlet, with yellow center, paling off toward the tips of the petals. See No. 3. Tubers, each 50c.

Geo. L. Christman-P. A dainty medium sized flower. on strong upright stem. Delicate mauve and lavender shades. L. E. D. Tubers, 50c.

Golden West-C. A beautiful California variety. The petais are quite broad and taper sharply to the point. Golden yellow, suffused bronze. Tubers, each $75 \mathrm{c}$.

Goiden Opportunity-S. Rich buttercup yellow, shaded burnt orange directly in center of each bloom. A sport from the best show Dahlia on record, Clara Seaton. One of our finest new varieties. See same form No. 11. L. E. D. Tubers, each $\$ 2.50$.

Garibaldi-P. Large flowering Dahlia, on good stem. Deep cherry, shaded maroon. Tubers, each $75 \mathrm{c}$.

Gold Crest-Dec. A beautiful golden yellow flower, on upright stem. Very prolific in bloom. Tubers, each $\$ 1.00$.

Golden Pheasant-P. Bright brick red and gold suffusion. Extra strong, and long stems. L. E. D. Tubers, each $\$ 1.00$.

Harvelia-P. Soft rose pink, lightly suffused with cerise. Blooms are quite large, while the plant is a strong robust grower. L. E. D. Tubers, each $\$ 2.50$.

Her Royal Highness-Dec.-P. Deepest rose to royal lavender. Very beautiful glossy foliage. Fine stem. L. E. D. Tubers. each $\$ 2.50$.

Hong Kong-P. Both beautiful and attractive. Oriental colors of deep buttercup yellow toward center, outer petals are shaded a deep tomato red. $\$ 2.50$. L. E. D.

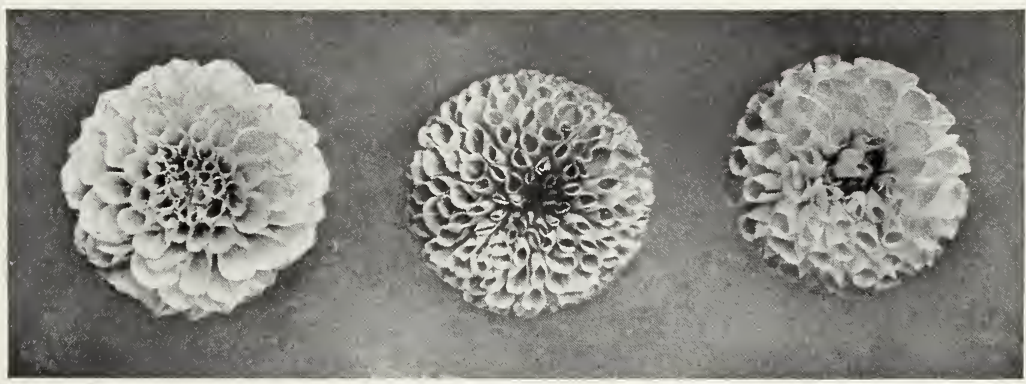


Hi Johnson-Dec. Deepest darkest velvety maroon, often marked paper white. L. E. D. Tubers, each $\$ 2.00$.

I. J. Lovink-P. A large, straight-petaled variety, of excellent quality; rose and lavender shades on white ground. Tubers, each $50 \mathrm{e}$.

H. G. Newman-Dec. A very deep cherry red Dahlia, with petals deeply lacerated at points. Long stems; an excellent cut flower variety. L. E. D. Tubers, each 75c.

Hortulanus Fiat-P. A seven to nine inch flower. Delicate shade of shrimp pink, the tip of each petal being barely toucher. with gold. Petals are broad and flat. Tubers, each 75c.

Hope Slater-P. Clear lemen yellow, shading lighter at tips of petals. Good stem. Exceptionally fine. Tubes, each $\$ 2.50$. L. E. D.

I. A. Hyde-Dec.-P. Giant flowering. Claret wine color, ofter with white markings. The florets are twisted and curved. A remarkable fine Dahlia. Tubers, each $\$ 2.50$. L. E. D.

Hollywood (in California)-P. Creamy yellow, suffused and daintily tinted blush pink and apricot shades. Tubers, each $\$ 2.50$. L. E. D.

Heart's Desire-C.-P. A giant flowering, new variety which is especially desirable for exhibition. Claret wine color. The petals are broad at the base, and taper to a sharp point. Prolific in bloom. L. E. D. Tubers, each $\$ 5.00$.

Heartsease-P. Peach tones, shading to flesh pink. Upright growth. Long wirey stems. Dainty as well as otherwise satisfactory. L.E. D. Tubers, each $\$ 1.50$.

Hocksai-P. Sulphur yellow, tinged brick red. Very free in bloom. Tubers, each 50c.

Harvest Moon-Dec. The color of this Dahlia is both unusual and beautiful, it being of a clear, light sulphur tone. Tubers, each $\$ 1.00$.

Helen Durnbaugh-Dec.-C. Delicate blush pink. Has been considered one of the best. Tubers, each $\$ 1.00$.

Issaquah-P. A good free flowering, rosy lavender, on good stem. Very showy when clumped in the garden. Tubers, each $50 \mathrm{c}$ or $\$ 5.00$ per dozen.

Jessie von Duesen Telford-P. One of our most recent introauctions. Giant flowering. The true peony flowering type. Bronzy copper tones, while each plant throws a number of blooms which are marked with snow white. Do you remember "Bertha von Suttner"? A Big "Bertha", could hide behind this Dahlia. L. E. D. Tubers, each $\$ 5.00$ 


\section{DEL MONTE, CALIF., U. S. A.}

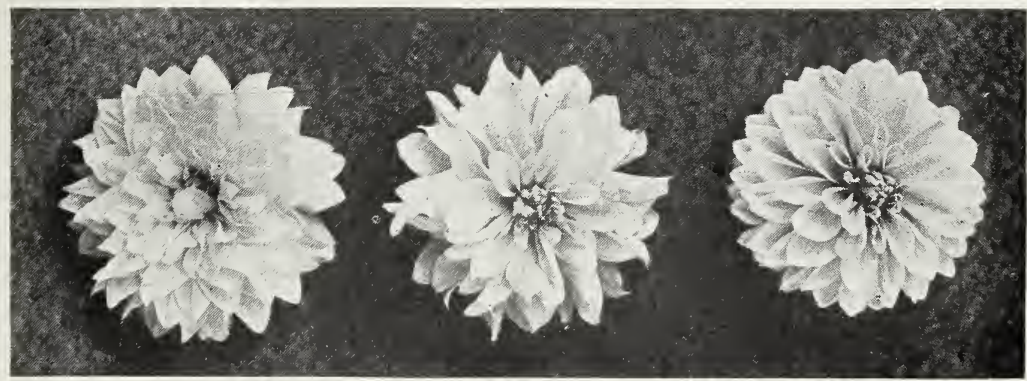

13

14

15

DECORATIVE TYPES

Jonixeer Borell-Dec.-P. Orange buff. A gcod Dahlia, on lon's, strong stem. Tubers, each 75c.

Jason-P. Another of our introductions that we most highly recommend. It is of richest burgundy color, shaded maroon. Of velvety texture. L. E. D. Tubers, each $\$ 2.50$.

Jupiter-C. Light pink, splashed crimson, yellow base. Petals incurved. Tubers, each $75 \mathrm{c}$.

John Riding-C. Deep, rich crimson. A large bloom with incurved petals. Tubers, each $75 \mathrm{c}$.

Johannesburg-C. One of the best. A large, straight-petaled Dahlia, of bronzy yellow colors. Tubers, each $50 \mathrm{c}$.

Jane Selby-Dec. This Dahlia is best described as being of the same color as the La France rose; a most beautiful shade of silvery rose pink. The blooms often measure eight to nine inches in diameter, and are thrown well above the foliage on long, stiff stems. See No. 9. Tubers, each $\$ 1.00$.

Jim Langford-P. A giant flowering variety of California origin. Blooms are quite double. Golden yellow, each petal suffused brick red, deepening toward center. Tubers, each $\$ 1.00$.

John Lewis Childs-Dec. Quite large. Blood red and gold, of ten marked white, also. New and attractive. Tubers, each $\$ 5.00$.

Justice Bailey-Dec.-C. Another very free flowering plant. Good sized blooms of shell pink, shading to white toward center. Tubers, each 75e.

John Dough of "OZ"-Dec. P. Giant flowering. Sulphur yellow. Robust in growth. Long stout stems. Tubers, each $\$ 2.50$. L. E. D.

Jessica-P. A very free blooming little flower of soft rose pink, suffused yellow. Graceful and pretty. Wiry stems. Tubers, each 50c. L. E. D. 
Kail-Dec.-C. A majestic flower, frequently measuring over nine inches in diameter. Glowing scarlet. Tubers, each $\$ 1.00$.

King of the Autumn-P. Giant new Dahlia with long, strong stems. Beautiful shade of burnt amber, with tinge of old rose. Tubers, each $\$ 1.00$.

K.enneth J. Doolittle-Dec.-P. Giant flowering, on splendid stem. The color is a crimson scarlet. Exceptionally fine. L. E. D. 1920 introduction. Tubers, each $\$ 2.50$.

Lotia-P. A very striking combination of orange yellow, light red and white. This is a very remarkable variety. L. E. D. Tubers, each $\$ 2.00$.

ieo XIII-P. Clear, deep yellow. Good sized blooms. A splendid Dahlia. Tubers, each 75c.

La Cigale-P. Blooms of most beautiful lemon yellow, shading deeper toward center. Tubers, each $\$ 2.50$. L. E. D.

La Americaine-Dec. Brightest clear cerise. A splendid companion for "La Cigale" or "Hope Slater". Remarkable coloring, and fine in every respect. Tubers, each $\$ 2.50$. L.E.D.

Lcila Hamilton-P. Giant star-shaped flower, of soft rose pink. Long, strong stem. Very fine. Tubers, each $\$ 3.00$. L. E. D.

La Zona-P. Large light yellow bloom, shaded bronze. This is from "Copper". Very free in bloom. L. E. D. 1920 introduction. Tubers. each $\$ 1.00$.

Latona-P. Light creamy yellow with tinge of amber. Erect stems. Tubers, each $\$ 1.00$.

Lou Colmore-P. A very large flower, with broad petals. A blend of orange, yellow and tan shades. L. E. D. Tubers each $\$ 1.00$.

L. Frank Baum (Royal Historian of " $O Z$ ') -Dec. Beautiful shade of salmon pink, with yellow suffusion. Robust growth. Tubers, each $\$ 1.50$. L. E. D.

La Favorita-Dec.-C. A beautiful large orange colored blossom. The plant has most excellent habits. One of the new Californians. Tubers, each $\$ 2.00$.

Little Mulberry-Single-P. A medium sized flower on upright stem. Color is very unusual, it being a dull mulberry red. L. E. D. Tubers, each 50c.

Lorwine-P. Quite single flowers of brightest cerise color. Fine stem. Tubers, each 50c. L. E. D.

Liberty-P. Loose, wavy petals of brightest salmon red. Tubers, each $75 \mathrm{c}$.

L. F. Kessing-Dec. Giant flowering. A truly wonderful Dahlia with a stout stem; color, watermelon red. L. E. D. Tubers, each $\$ 2.00$. 
Le Grand Manitou-Dec. Large white flower, streaked violet purple. Tubers, each $75 \mathrm{c}$.

Marabilis-P. A wonderful new Dahlia, which is especially fine for exhibition, as it will grow larger than any other variety we have when it is at its best. Tariously marked lemon yellow and white. The petals are twisted and curved. L. E. D. Tubers, each $\$ 2.50$.

Meyerbeer-P. A very long stemmed rariety, while the bioom is of immense size. Color, purplish wine, shaded maroon. Oí intense coloring throughout. Tubers, each $\$ 1.00$.

Marston-P. Brick red and tan shades. Medium to large; very free in bloom. L. E. D. Tubers, each $\$ 1.00$.

Mme. Van den Dael-P. Softest silvery rose pink. Tubers, each $50 \mathrm{c}$.

\section{LETTERS FROIM SATISFIED CUSTOMERS.}

J. R. J., West Chester, Pa., writes us: The "L. R. Kessis." is much admired by everyone-have an immense bloom $0:$ it. "Jane Selby" is a beautiful pink- "Mrs. W. E. Estes" is the finest white I ever saw- "Mrs. J. N. Jarrett", the Dahlia you gave me gratis, has fine blooms. Last season I paid for an "Earle Williams" which you could not supply, and are to send another season-a friend saw this Dahlia at the Delaware State Fair, and it was the finest Dahlia in the show.

Mrs. E. L. E., Allston, Mass., writes: Had some Dahlias from your place, last season-they were wonderful-please send Catalogue.

J. R. C., Santa Monica, Calif., says: Am enciosing my check for \$- and will be delighted if we have the same wonderful success as last season-had fifty tubers, and they were the wonder of the town-all grew but two.

From Z. and R., Florists, Trenton, N. J.: Shipments received-everything all $O$. K.-each tuber in good shapenot a broken neck.

S. H. W., York Blvd., Los Angeles, writes: Please send me your latest Cato.-also one to —_ the Dahlias I receired the first of the year are beanties, full of buds, and now begimning to bloom. 


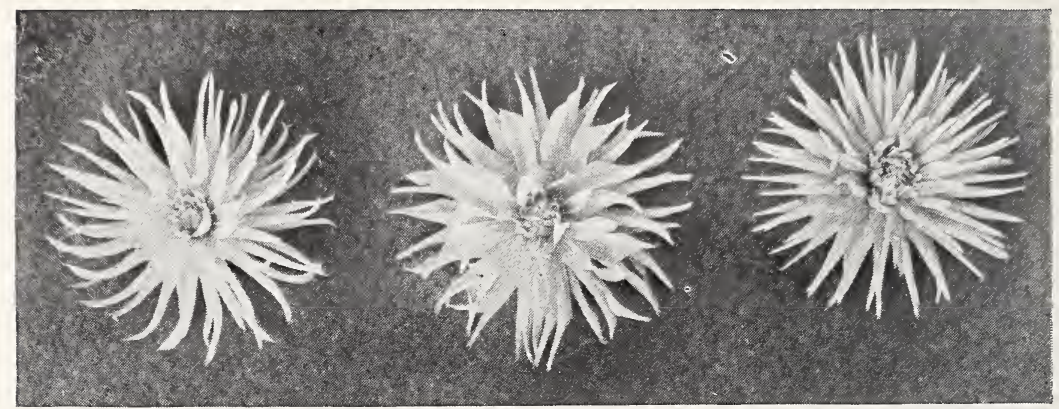

16

CACTUS TYPES

Mondschiebe-An upright flowering Dahlia of great merit. Broad, pointed petals; clear canary yellow. Tubers, each 75c.

Mrs. Geo. Pope-Dec. Very large flowering, creamy yellow with a suggestion of rose. Tubers, each $\$ 1.00$.

Merci-P. Most delicate, soft satiny pink. A semi-double flower, somewhat pointed at the tips. This Dahlia is another seedling from "Sweet Remembrance", much lighter in color. and with its extra long, strong stems is an exceptionally fine cut flower variety. L. E. D. 1918. Tubers, each $\$ 1.00$.

Mrs. W. E. Estes-Dec.-C. A very fine, new, snowy white Dahlia of much merit. Broad and long, pointed petals, forming a flower of great size. This is easily our best white Dahlia to date. Tubers, each $\$ 1.50$.

Mrs. Garrett Roest-P. A new type of Dahlia; comes quite single, the petals being well rounded at the tips, while the color is golden yellow, with a suggestion of pink. The bright yellow center is of exceptional size. Another fine cut flower. L. E. D. Tubers, each $\$ 1.00$.

Martha Loewi-S. A beautiful quilled Dahlia of old rose shades, it being identical in form to the well-known "Clara Seaton," from which variety it is a "sport". These two with the "Golden Opportunity", another "Clara Seaton" sport, make a wonderful color combination. L. E. D. Tubers, each $\$ 2.00$.

Maybelle Eckland-P. Of exceptional merit. Maroon and wine shades. L. E. D. Tubers, each $\$ 1.50$.

Mrs. Edna Spencer-Dec.-C. An exceptionally delicate shade of lavender, or orchid pink. Very beautiful, and with good stem. Tubers, each $\$ 1.50$.

Write us about your success - we like to know. 
Mrs. Warnaar-Dec.-C. A beautiful Holland introduction, on good stem. Creamy white, tinted delicate pink. An exquisite flower. Tubers, each 75c.

Mrs. J. N. Jarrett-P. Brightest blood red, each petal suffused and tipped gold. A very fine, attractive, and very early blooming variety. L. E. D. 1918. See No. 3. Tubers, each $\$ 1.00$.

Mir. J. Emberson-C. Pale lemon yellow, splashed with pink. Excellent. Tubers, each 50c.

\section{YOU MAY EXPERIENCE THE SAME SUCCESS.}

A card from D. F. B., Berkeley, Calif,. reads: The tubers arrived in fine shape-now have them planted, and all are coming nicely.

A card from J. C., No. 25 Madison Ave., N. Y. City, as fol F $_{-}$ lows: The Dahlia tubers arrived O. K. and their appearance depicts the care and attention given by you-thank you for the complimentary tuber.

C. G. W., of Collingswood, N. J., writes us about our "Radiance": Everyone who has seen my garden, has offered good remarks about "Radiance", -it attracts more attention than any flower I have ever grown, both at the Show, and in my garden-if you have others as fine, please let me know.

From S. M., New Orleans, La.: It will interest you to learn that the Dahlias which my sister ordered of you, produced the finest flowers of their kind in N. O.- shall be pleased t') rccommend your Dahlias.

Mrs. Leslie C., Nashville, Teun., writes: We were very successful with the Dahlias bought of you.

James E. D., Westville, Conn., says: I won the prize for the largest Dahlia in the Show-tubers bought of you. Would like to have the following varieties -

From Barrington, N. J.: Have just been to southern part of state, and have seen some of your Dahlias, and they are fine-I understand from friends that you send out stock "true to name" - you are the one I wish to deal with-please scnd your Catalogue.

O. R. S., McGee Ave., Berkeley, Calif., says: "Maybelle Eckland" is a dandy-the envy of all the growers around here. 


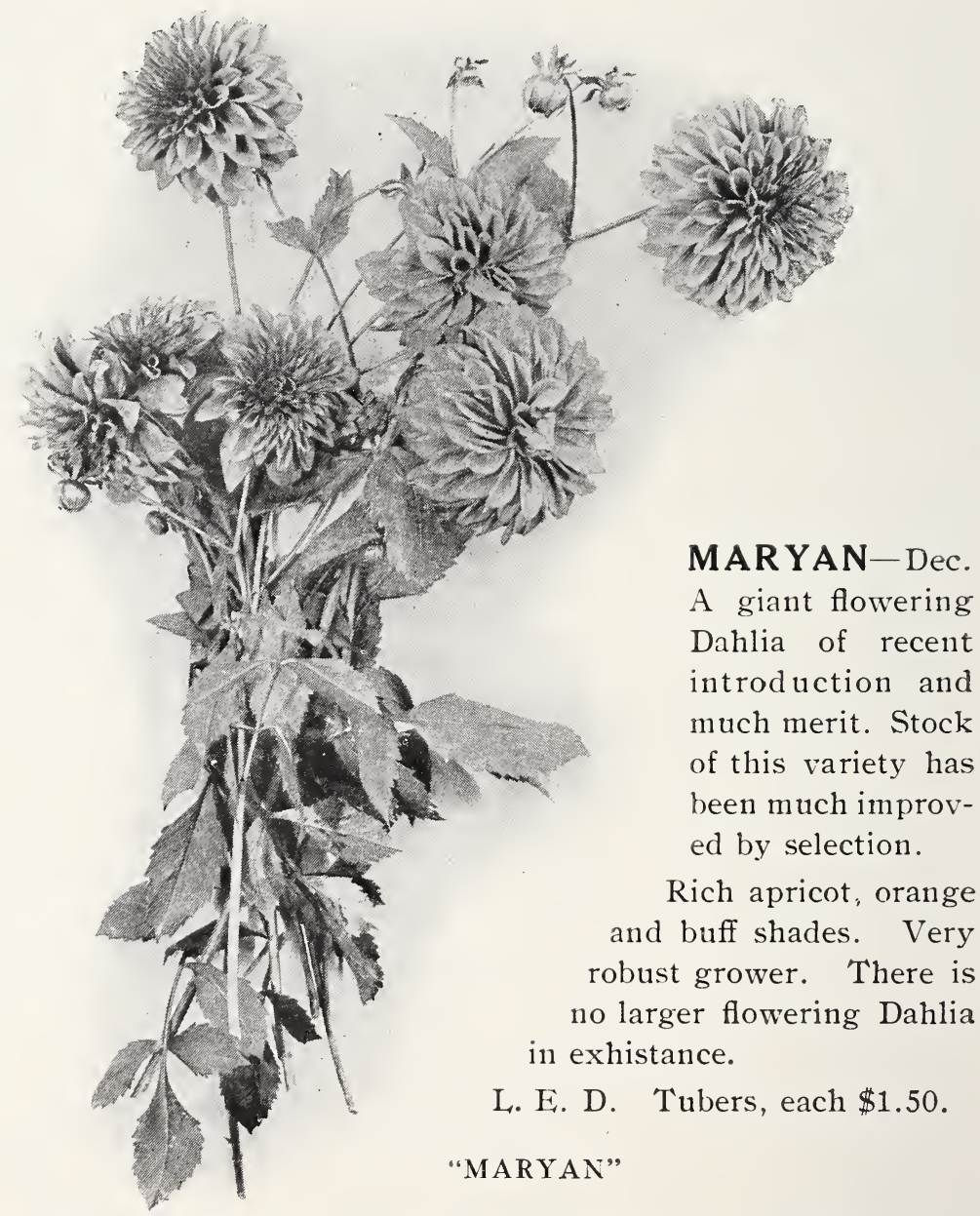

Mrs. R. D. Robinson-P. A partly reflexed petal, twisted and curved in a pretty and unusual manner. The best canary yellow to date. Tubers, each $50 \mathrm{c}$.

Mons. Capron-Dec. Light maroon, edged white. A very attractive bloom. Tubers, each 50c.

Mother 0'Pearl-P. A very robust grower, with long, upright stem. A large flower of softest yet deep rose shadings on white ground. Tubers, each $\$ 2.50$. L. E. D.

No old (mother) tubers ever sent to my customers. 
Mrs. Frances Key Pendleton-P. Violet to deepest rose, shaded relvety carmine, with white markings throughout. Tuber's, each $\$ 2.50$. L. E.D.

Mary Franklin Zane-P. Large flowering variety, star-shaped, with twisted florets. Deep carmine-rose and lemon yellow shades. Very attractive. L. E. D. Tubers, each \$5.00.

Miles Standish-Dec. Deepest transparent rose, heavily shaded carmine throughout. Strong grower and good stem. Tubers. each $\$ 1.00$.

Maud G. Baum-P. The first blooms of this variety are especially iarge and all are of good size. Coloring is of soft rose pink shades. This is an especially desirable Dahlia. L. E. D. Tubers, each $\$ 2.50$.

Mrs. Carl Salbach-Dec. An immense bloom of lavender pink. A perfect Exhibition variety, and one of the new California prize wimners. Tubers, each $\$ 3.00$.

Mrs. J. T. York-Dee.-P. Deep maroon and wine shades, often with white markings. L. E. D. Tubers, each $\$ 1.00$.

Mine. Renard-C.-P. A coral pink flower, with amber shadings. Both dainty and beantiful. Tubers, each $\$ 1.00$.

Mrs. C. H. Breck-Dec.-C. Wonderful blooming qualities. The colorings are a combination of cream, lemon, and rosy carmine. Tubers, each $75 \mathrm{c}$.

Mrs. F. C. Burns-A Novelty. This beantiful shell pink decorative is one of the best for all purposes and never fails to attract attention by its lovely coloring. A prize wimner. $\$ 2.00$.

Maroon King-Dec. Very free in bloom, and of large size. Deep velvety maroon. Very beautiful. L. E. D. Tubers, each $\$ 2.50$.

Myrtle's Beauty-A dainty, medium size bloom, on wiry stem. White and French pink suffusion. Tubers, 75e.

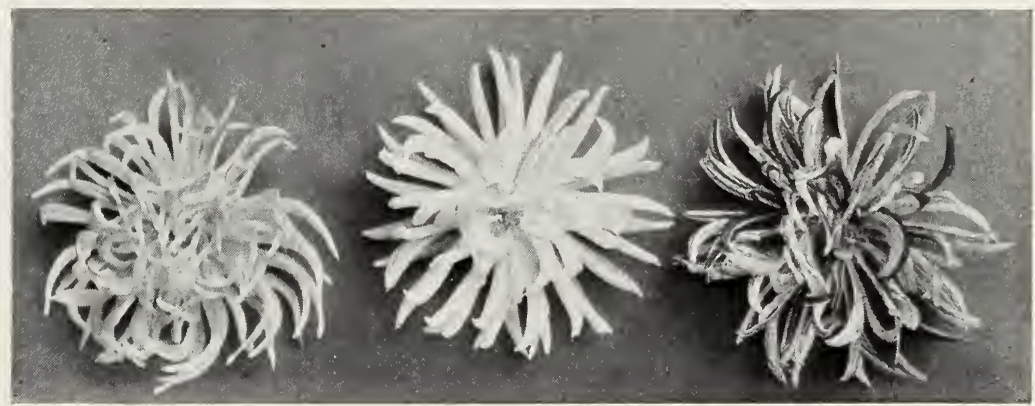


Mary Purrier-C. The best crimson scarlet in this type. We have extra fine stock of this. Tubers, each $75 \mathrm{c}$.

IIagnificent-C. Rosy salmon pink, of satiny appearance. Tubers, each $\$ 1.00$.

Mrs. E. V. R. Whitcomb-P. A long-stemmed variety. Pure white. Looks to be artifically made of crepe paper. Early. 1920 introduction. L. E. D. Tubers, each 75c.

Morning Star-P. This is one of the finest varieties in the Dahlia world. Deep cherry red, often marked paper white, which with this variety is an added attraction. Free in bloom and always of good size. L. E. D. Tubers, each $\$ 1.50$.

Melba-Dec.-C. Long, narrow petals of a clear cerise. Tubers, each $75 \mathrm{c}$.

Mrs. R. B. Eliot-Dec.-S. Snow white flower with quilled petals. Tubes, each $75 \mathrm{c}$.

Minna Burgle-Dec. Intense crimson-scarlet. Keeps well when cut. Tubers, each 25c. 1 dozen for $\$ 2.50$.

Masterpiecє-P. A creamy yellow with golden tinge. Upright growth. Tubers, each $50 \mathrm{c}$.

Nioelungenhort-C. Somewhat on the Decorative type, it having quite broad petals of amber shading to salmon pink. Excellent. Tubers, each 75c.

Ncbiiis-Dec. This is almost a counterpart of the variety "Earle Williams" c $f$ which it is a sport. It is of identical coloring to the latter, excepting that in this variety the white predominates, and the bloom is, perhaps, an inch smaller in size, yet this is a splendid Dahlia. Crimson and white. L. E. D. Tubers, each $\$ 2.50$.

Odüity-P. A new type of Dahlia. Rose lake in color, each petal prettily bordered white, and curved inwardly at edges. L. E. D. Tubers, each $\$ 1.00$.

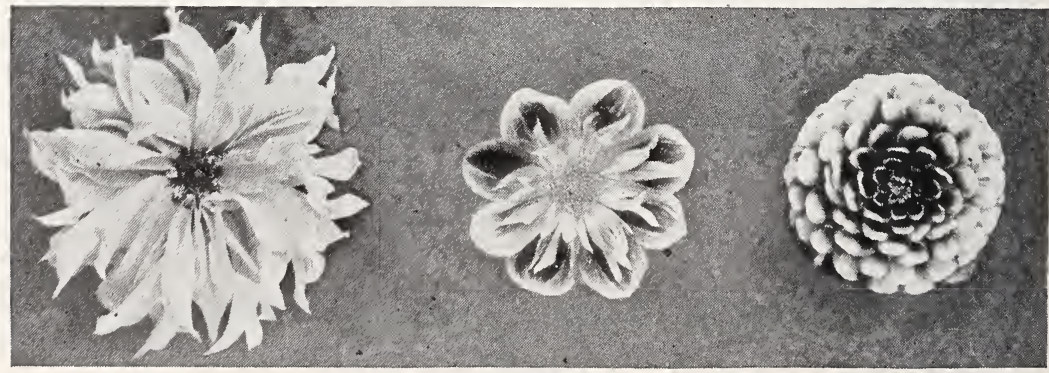


Ohio Belle-P. Canary yellow. Quite double, with long stem, and also very prolific in bloom. Tubers, each $\$ 2.50$.

Orange Glow-P. A good sized bloom of light orange color. Tubers, each 50e.

Oriana-P. A beautiful and good sized Dahlia. Upright stem. Coloring is orchid pink. Tubers, each 75c.

Ozcot (Home of L. Frank Baum, at Hollywood)-Dec. Copper and bronze tones, intermingled with apricot pink. Exceptionally good. Tubers, each $\$ 2.50$. L. E. D.

Oasis-P. Long star-shaped petals. White, shaded heavily with earmine. Tubers, each $\$ 1.50 .1920$ introduction. L. E. D.

Olympic-C. A very large flowering Dahlia. Cardinal red. Tubers, each $75 \mathrm{e}$.

Orange Doazon-Dec. Mammoth in size, with broad petals and fine stems. A rich shade of orange red. Tubers, each $\$ 2.00$. Paramount-P. White, suffused carmine rose. A good new variety. Very attractive. L. E. D. Tubers, each $\$ 1.50$.

Pathe-P. Giant flowering. Cerise to carmine, shading lighter at tips of petals. L. E. D. Tubers, each $\$ 2.50$.

Perle Ruggles-P. A splendid new variety, introduced by its namesake. Ground color is white, suffused with rosy carmine pink. Tubers, each $\$ 2.50$.

Pride of California-Dec. Throws good large blooms of a deep red color, on upright stem. Tubers, each $\$ 1.00$.

Princess Pat-Dec. In my opinion, one of California's best Dahlias. Beautiful shade of old rose. Stout stems, and blooms are of excellent size and type. Tubers, each $\$ 2.00$.

Pierrot-C. Deep amber, tipped pure white. Very large, and also prolific in bloom. Tubers, each $75 \mathrm{c}$.

Purple Manitou-Dec. Large flowering, and on g rod strong stem. Royal purple. 'Tubers, each 75c.

Queen of Violets-P. A beautiful flower from every point of view. A solid color, between roselake and violet. L. E. D. Tubers, each $\$ 2.50$.

Rosalie-P. Beautiful large blooms on graceful, strong stem. Very free in bloom. White, heavily shaded rose, especially so on back of petals. L. E. D. Tubers, each $\$ 2.50$.

Radin Kartini-P. Salmon pink, with yellow vein throughout. Upright stem. Very pretty. Tubers, each $\$ 1.00$.

Rose Fair-Dec.-P. Another free flowering Dahlia, on long wiry stem. The color is soft rose pink. Tubers, each 75c.

Ruby-P. A large ruby red flower, with tinge of velvety maroon. Extra long stems. Very desirable. L. E. D. Tubers, each $\$ 1.50$. 


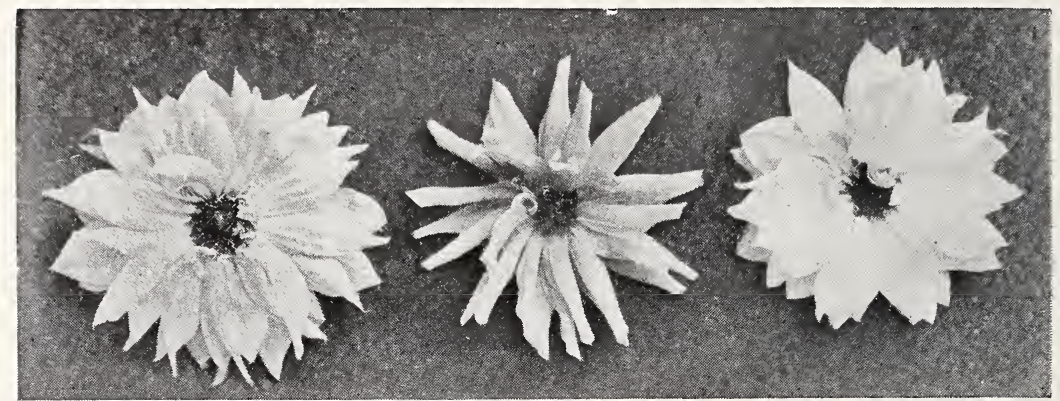

25

26

27

PEONY FLOWERING TYPES

Roselake-P. Beautiful star-shaped flowers. The coloring is a wonderful, bright shade of roselake. Something new. L. E. D. Tubers, each $\$ 2.50$.

Realization-P. Brightest buttercup yellow. A new California Dahlia of merit. Introduced by Mr. H. E. Sies. Tubers, each $\$ 3.50$.

Radiance-Dec.-P. We have no Dahlia that is brighter, or more attractive than this variety. No two blooms are just alike. Of most intense coloring. A combination of colors, being cerise, purple, and with white markings. Does especially well in the Eastern States. It is a giant in size. L. E. D. Tubers, each $\$ 10.00$.

R. 0. Burton-P. Creamy white. An early and prolific blooming variety with good stem. A cut flower variety. L. E. D. 1920 introduction. Tubers, each $\$ 1.00$.

Riseinischer Frohsinn-C. White at base, overlaid with earminerose. Very beautiful. Tubers, each $75 \mathrm{c}$.

Radiant Happiness - Single. Carmine rose, with lemon yellow shadings toward the golden yellow center, and with each petal tipped creamy yellow. Brightness personified. Guaranteed to cure the worst case of blues. Prolific in bloom. Tubers, each $\$ 1.00$. L. E. D.

Seabright-Dec. Rich apricot to buff. Fine stems. Tubers, each, $50 \mathrm{c}$.

Sweet Remembrance-P. A general favorite. Bright yet soft pink. This variety is semi-double, with a beauty that baffles description. Very free in bloom. L. E. D. Tubers, each 75c. Sulphur Gem-Dec. Soft, light sulphur yellow, on good stems. Tery free in bloom. Tubers, each $75 \mathrm{c}$. 
Suv. Franz Liszt-P. Almost single, of good size, wonderful blooming qualities, good stems, and beautiful coloring; glow. ing rose to violet white, with bright yellow center. Tubers each 50e. See No. 29.

Santa Maria-Dec. Giant, cream colored bloom, with soft shades of pink suffused throughout. The stem is pendent, but the blooms are exceptional. L. E. D. Tubers, each $\$ 2.50$.

Siveet Maryland-P. Soft pink and yellow shades. Good stems. L. E. D. Tubers, each $\$ 1.00$.

Scotish Chiff-Dec.-P. Copper to terra cotta, often with white markings. Tubers, each $75 \mathrm{c}$.

Silician Beauty-P. Combination colors of cerise, maroon, and white. Very pretty. Tubers, each $\$ 1.00$.

Sunset's Glow-Dee. This Dahlia has all the tints of a sunset's glow. Splendid flowers on exceptionally strong stem. L. E. D. Introduction. Tubers, each $\$ 1.00$.

Snowden-C. One of the best eactus varieties. Snow white; long, sharp-pointed petals. Tubers, each 50c.

Santa Barbara-Dec.-P. Soft pink and yellow shades. Satiny and rich in beauty. Tubers, each $75 \mathrm{c}$.

Sweet Brier-C. Soft, silvery, shell pink. Petals slightly ineurved. Tubers, each $75 \mathrm{c}$.

Sunshine-Dec. A large flower with broad peals of bright red and gold. Very fine flowering. A new California Dahlia. Tubers, each $\$ 1.00$.

The Screamer-Giant sized flower, two to three rows of petals. Extra long strong stems. The coloring is violet purple, suffused mauve. This Dahlia is exceptional. L. E. D. Tubers, each. $\$ 10.00$.

The Bumble Bee's Wonderland-P. A pleasing shade of mauve pink, heavily marked earmine to violet rose about the yellow dise. Very fine. L. E. D. Tubers, each $\$ 2.50$.

The Bronze Orange-P. Bright tones of orange and bronze. Quite double, and free in bloom. L. E. D. Tubers, each $\$ 2.50$.

The Lyons-C. An incurved petal, bloom of good size, and the color of the Lyons rose. Amber to flesh pink, with a suggestion of flame. A bold, fine flower. Tubers, each $75 \mathrm{c}$.

The Sawhorse of "OZ"-P. A beautiful flower of tan and apricot tints, suffused with yellow. Long, sharp pointed petals with wavy effect. Free in bloom. Tubers, each $\$ 1.50$. L. E. D.

The Yellow Hen of "OZ"-Dec. P. Clear canary yellow. Long and strong stem. Good yellow Dahlias are searce. This one is fine. Tubers, each $\$ 1.00$. L. E. D. 
The Wizard of $\mathbf{O z}$-Dec. Has a slight tendency toward the "cactus" type, as shown in cut of same, on this page. This is, in our own opinion, the finest Dahlia in existence today. Read what others say of it. It is a veritable Giant of a "Wizard", and a 100 per cent Dahlia, all the way. The color is a rare shade of glowing amber pink, or soft salmon shades. It is a Dahlia difficult to describe. An L. E. D. Introduction. Tubers, each $\$ 20.00$.

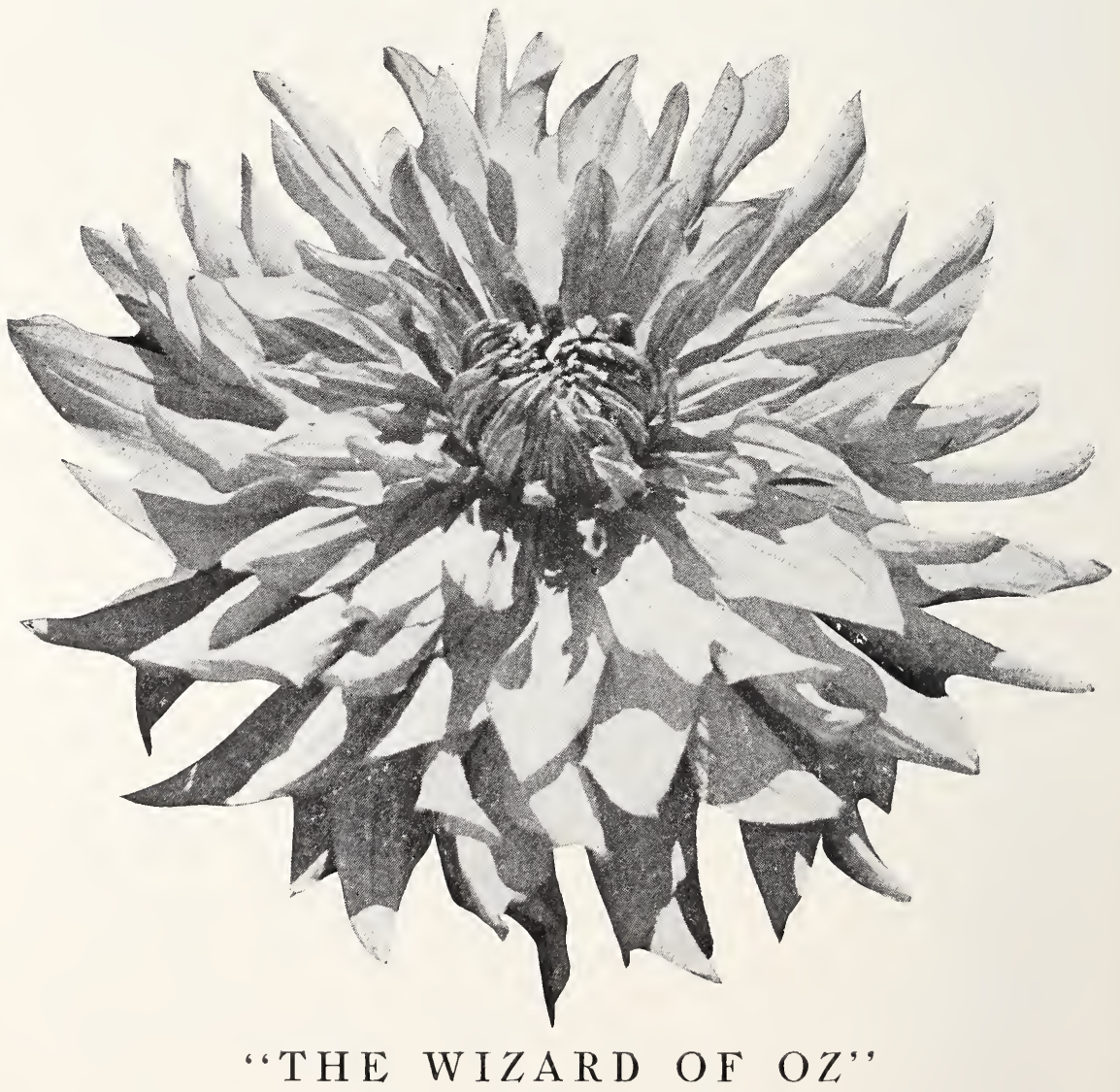

FAMOUS for Beauty of Color, for it's Hardy Upright Growth and it's Remarkable Size. 


\section{WONDERFUL REPORTS FROM S. F. TO NEW YORK}

A Grower-J. L. S., 607 Third Ave., San Francisco, saysThe "Wizard of $\mathrm{Oz}$ " is very beautiful-had one bloom 12 inches in diameter.

J. T. B.-Santa Paula, Calif., writes-

My "Wizard of $\mathrm{Oz}$ "' has been perfectly wonderful-have cut over a dozen blooms from it, already, and people who see it, exclaim and hold their breath. They say-" "It is the most beautiful Dahlia I have ever seen.', What else have you that you think I would like the coming season? Ella Naomi Pierce and La Favorita both fine.

Mrs. J. R.-Glendale, Calif., writes-

"The Wizard of $\mathrm{Oz}$ " is a wonder in this climate. Harvelia, too, is splendid.

Mr. E. A. A.-Grower-Trenton, N. J., writes under date of Oct. 19-21. Please quote me on six divisions of your "Wizard of Oz". This Dahlia certainly caused a sensation when I exhibited it at the New York Dahlia Show this fall.

The Magic Carpet of 'OZ',-P. Creamy yellow, tinged with apricot pink. Another flower of daintiest colorings. Tubers, each $\$ 1.00$. L. E. D.

The Magic Flower of 'OZ',-Dec. P. Light coppery yellow, shaded with bronze. Very hardy. Long stems. One of the finest. Tuber's, each $\$ 2.50$. L. E. D.

The Little Pink Kitten of 'OZ' - P. Soft blush pink, shaded amber. The bloom is five to six inches in diametr. Long, strong stem. Tubers, each $\$ 1.50$. L. E. D.

The Cowardly Lion of "OZ" -Dec. Rich golden apricot, tinged both buff and burnt orange. Extra upright stem. Tubers, each $\$ 2.50$. L. E. D.

The Wax Doll of "OZ' - P.-Cactus. A medium size bloom of most beautiful soft tones. A splendid cut flower. Waxy creamy white, tinged lavender toward tips of petals. Recommended to those who desire delicate shades. L. E. D. Tuber's $\$ 2.50$.

The Little Brown Bear of "OZ' - Single-P. A pretty bloom of mahogany red to brown. Very prolific in number of blooms. Strong stems. Tubers, each $\$ 1.00$. L. E. D. 


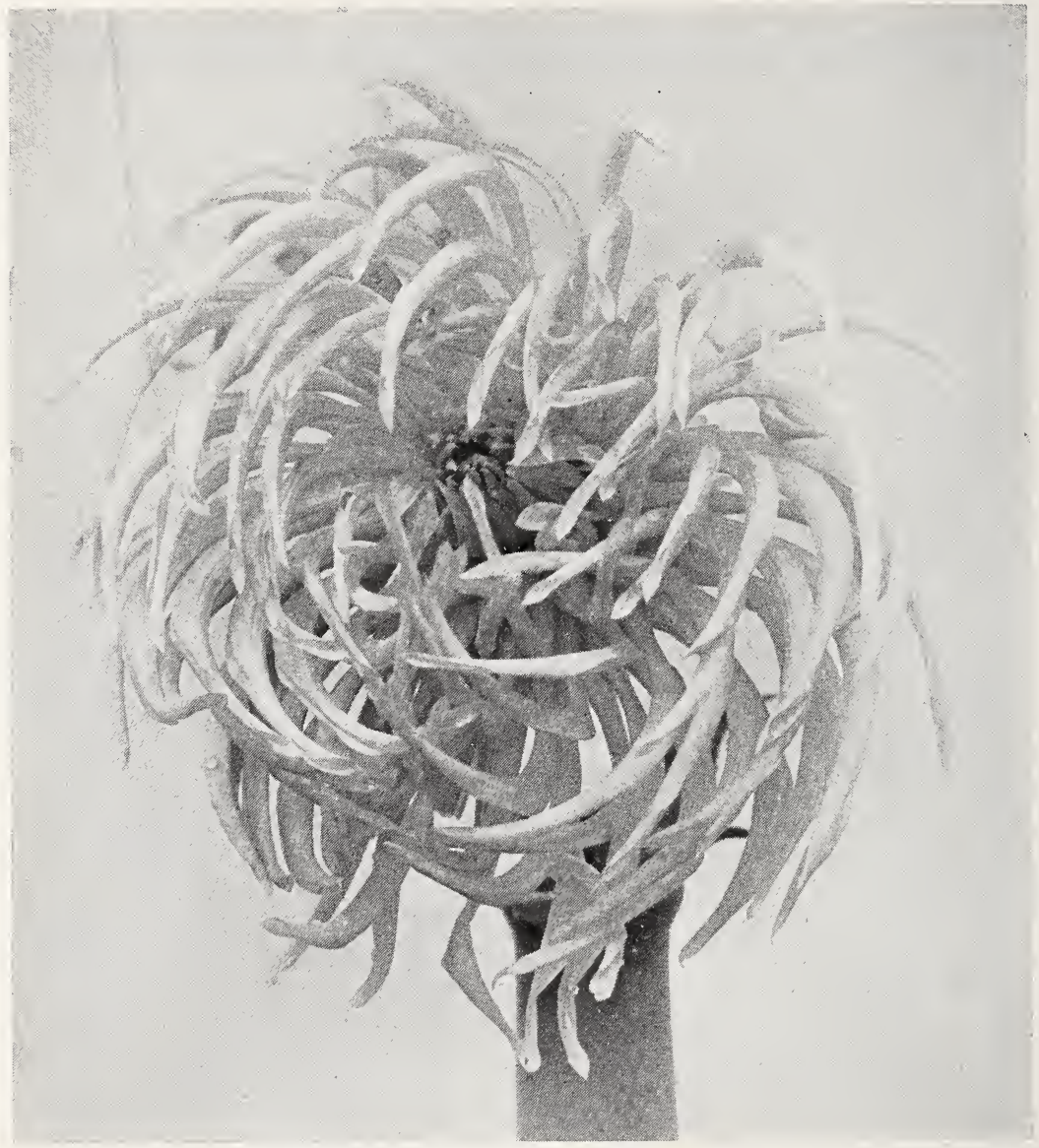

CACTUS DAHLIA-“THE LYONS"

The Tik Tok Man of "OZ', - P. From "Morning Star" by "Gejsha'. A treat to the fancier. Petals have the loose wavy effect, yet of good substance. The colorings are a combination of lemon cream and carmine. L. E. D. Tubers, each $\$ 2.50$.

The Shaggy Man of "Oz',-Dec.-P. Long shaggy, sharp pointed petals. Of good size, and upright hardy growth. The coloring is deep claret wine, tipped and marked with white. L. E. D. Tubers, each $\$ 2.50$.

If you were once a customer, you will be again. 


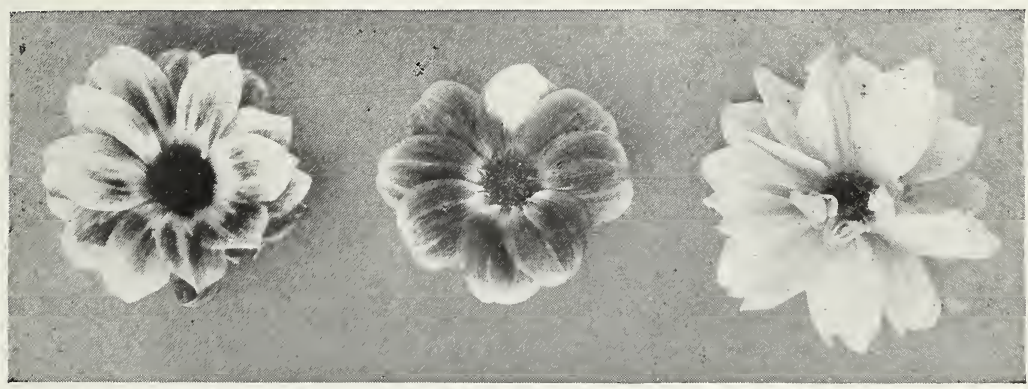

28

PEONY TYPE
29

SINGLE
30

The Little Artist-P. A dainty bloom, on good stem. Apricot shades, tipped cream. Tubers each $\$ 1.00$.

Traufners Choice-Dec.-C. Soft rose pink. Very free blooming. Tuber's each $\$ 1.00$.

The Hungry Tiger of $\mathbf{O z}-\mathrm{P}$. Another very fine Dahlia. Large flowering, and very free blooming. Creamy yellow, heavily tinged with apricot shades. L. E. D. Tubers each $\$ 2.50$.

The Millionaire-Dec. This is one of the finest large decorative type Dahlias yet introduced, of which my present stock is exceptionally good. A beautiful shade of lavender, which color lightens and darkens in accordance with weather conditions. Good stems. Tubers, each $\$ 2.00$.

Tonopah-P. Golden yellow, suffused bright brick red. The entire bloom is overlaid with a golden sheen. Broad petals, rounded at tips. The flower has a prominent golden yellow disc. Good stems, and free in bloom. L. E. D. 1920 introduction. Tubers, each $\$ 1.00$.

The Grizzly-A novelty. One of the best of Frank C. Burns. A great dark velvety maroon beauty. Flowers are extra large with reflexed petals, extra long stems. A rare prize winning novelty. $\$ 2.50$.

Tom Lundy-Dec.-P. Another giant flowering California introduction. Deep red, with still deeper shadings. Tubers, each $75 \mathrm{c}$.

The Chocolate Soldier-C. Stands up like a soldier, and looks you in the eye. The best stem ever. The color is a rich chocolate maroon. Size, 8 to 9 inches in dianeter. L. E. D. Tubers, each $\$ 10.00$.

Every Dahlia tuber is well sprouted when sent out. 


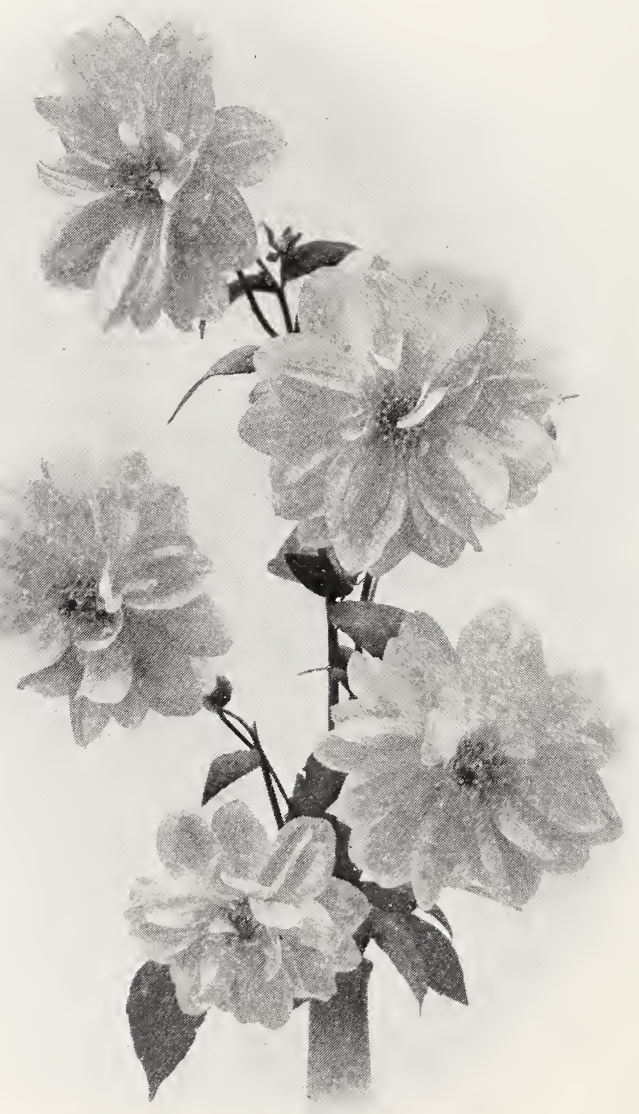

THE "LITTLE PINK KITTEN" OF OZ

Uncle Henry of $\mathbf{O z}$-Dec.-Show. Deepest rose, or deep lilac color, on wonderful long stem. The bloom is of good size, and is a Dahlia much admired. L. E. D. Tubers, each $\$ 2.50$.

Vasanta-C. "Goddess of the Four Seasons'. Rich apricot and golden yellow shadings. L. E. D. Tubers, each $\$ 5.00$.

Velvet Beauty-Dec.-P. Deep cherry red, of richest velvety texture. L. E. D. Tubers, each $\$ 2.50$.

Good true stock-good service. 
Whidby-Single-P. Of most delicate coloring. Flesh or blush pink, on white ground. An excellent stem. Tubers, each $\$ 1.00$.

Woozy of "OZ"-Dec. Creamy pink, with just a suggestion of deeper tones of rose pink. Large and free flowering." One of the best. Tubers, each $\$ 2.50$. L. E. D.

Wallace E. Doolittle-Dec. A new shade of watermelon red. Giant flowering. Free in bloom, and with good upright stem. Tubers, each $\$ 2.50$. L. E. D.

Wodan-Dec.-C. Delicate old rose and salmon shades, changing to old gold toward center. Very fine. Tubers, each 75c.

Yellow King-Dec.-C. A very large bloom on a small plant. The color is creamy yellow. Very good. Tubers, each $\$ 1.00$.

Yellow Collose-Dec.-S. Canary yellow. Tubers, each 25c.

\section{DOOLITTLE'S DAHLIAS CAME OUT ON TOP}

A letter from Mr. F. J. MeC., Santa Maria, Calif., informs us as follows-You will be glad to know how we came out with cur first Dahlia Show-Doolittle's Dahlias came out on top. I received First prize for Best General Collection of Dahlias in the Show, also First Prize for Best Dahlia in the Show, with your "Vasanta", again won First Prize for Best Vase of Pomprns-also Three Blue Ribbons. I did not have a Dahlia in my garden, nor in my exhibit, other than those received fr:m you. We had a remarkable Dahlia Show, people coming from all over the Valley-the Show would have been a credit to a much larger city.

Another letter reads-"Radiant Happiness" everyone delights in. "Ozcot of Oz" is beautiful, as is "Woozy of Oz", also. "Vasanta" is truly gorgeous.

M. von P. of Pasadena writes us-The Dahlias sent me are all in bloom, and they are a joy, the "Woozy of $\mathrm{Oz}$ " and "The Nilionaire" we particularly delight in.

Dr. M. C. MI-S. of Los Angeles says-I enclose photos of my first blooms "Maybelle Eckland" and "Dr. H. L. Tevis" - the foliage is perfectly clean, the entire plant in each case, is vigorous and strong, without the slightest flaw. I grow them without any artificial support. I am very well satisfied with the collection you sent me. 


\section{HOW TO ORDER}

The foregoing list of Dahlias are all splendid varieties, and one cannot mistake in ordering any or all of them. If it so happens that you are already growing Dahlias, it might be well to select from this list, so as not to duplicate varieties that you already have. In ease you have no Dahlias at all, or none of $\mathrm{my}$ introductions, I strongly urge that the selection be left to my discretion. In doing this, you are putting me upon my honor and at the same time, as you no doubt now realize, you would be in the hands of a specialist, in Dahlias. We fill many orders of this sort, and are enabled to give special prices upon our own selection, as follows - 100 tubers for $\$ 75.00,50$ tubers for $\$ 40.00,25$ tubers for $\$ 21.00,12$ tubers for $\$ 11.00$. These include varieties ranging in individual values, from $75 \mathrm{c}$ to as great as $\$ 5.00$.

All prices quoted in this Catalogue, include postage, so that only the amount of the order should be sent us. We acknowledge receipt of all orders and payments. Every tuber may be expected to be marked with the correct name and description, and full printed instructions in Dahlia culture, will accompany each order. All orders sent in the Spring, after danger of frosts, unless we receive other instructions from the customer.

\section{Pompon Dahlias}

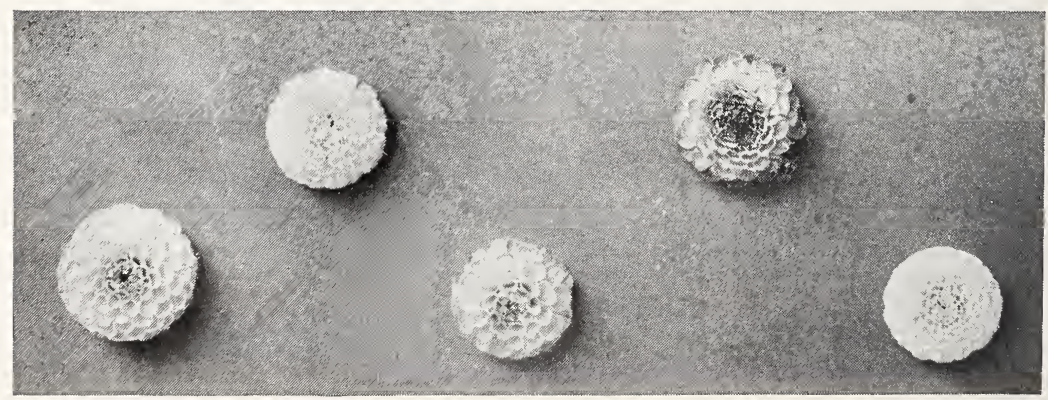

The Pompon type of Dahlia, is that pictured above, the "Baby" Dahlia of them all. At first glance, one not acquainted with this type would think that it belonged to another sphere, other than the Dahlia World. Nevertheless, these are a very popular little plant, and are especially so for a cut flower, as they are often kept a week's time. These plants grow quite low, and should be a mass of bloom all season.

The Dahlia is one plant that thrives in all climates. 
We offer a splendid selection of these at $50 \mathrm{e}$ each or a dozen may be had for $\$ 5.00 ; 50$ tubers for $\$ 20.00$, or 100 tubers for $\$ 40.00$.

Amber Queen-A long stemmed variety. Golden amber. Achilles-Delicate lavender, tinted lilac.

Arthur Kerley-Deep rich cherry red.

Annie Doncaster-Autumn tints, shaded soft lavender.

Bobby-Splendid form. Magenta to plum color.

Bronze Beauty-A pretty golden bronze colored little bloom.

Cheerfulness-Cream, shaded soft pink.

Clarissa-Delicate flesh pink, beautifully quilled.

Donovan-White, deeply tinged lavender. Very satisfactory.

Darkness-Very dark. Maroon to chocolate.

Dew Drop-White, softly shaded lavender. A beauty.

Fascination-Very fine. Pink and lavender shades.

Gloria-Maroon, wine, and white. New and splendid.

Geo. Ireland-Lavender to mauve.

Gretchen Heinie-Pale yellow, tinged brick red. A favorite.

Glow-A pretty, deep shade of old rose.

Harry Snook-The daintiest of little blooms. White, delicately shaded pale pink.

Hecla-Creamy white.

Helen Lambert - Canary yellow.

Henrietta-Deep sulphur yellow, bordered rosy lilac. Fine.

Ideal-Clear canary yellow.

J. Fette-A splendid pure white.

Leader-One of the best. Clear light lemon yellow.

Little Jennie-Straw color. None prettier than this one.

Little Beeswing - Golden yellow heavily marked cherry red.

Little Johnny-Deep maroon. Very small.

Nemesis-Variegated. Red and white. Very attractive.

Nellie Fraser-A light shade of pinkish lavender.

Prince Charming - Lavender shades, touched with violet and deep rose.

Pure Love-A pure lavender.

San Toy-One of the favorites. White, tinged carmine.

Spy-Brightest vermillion.

Sunny Daybreak-Yellow and orange red suffusion.

Snowclad-Pure snow white.

Sunbeam-Crimson scarlet. Very bright.

Sunset_Orange color. Always desirable.

Vivid-Brightest scarlet.

Winifred-White. One of the most beautiful of all pompons.

Observe the quality of workmanship on Dahlia tubers sent you 


\section{Collarette Dahlias}

These are a type which are quite single, excepting that they have a row of shorter petals about the yellow dise, forming a collar. The collar is often of a contrasting color, which lends brightness and beauty. The blooms are from four to five inches in diamer. 50e each, or the 9 varieties listed below may be had for $\$ 4.00$.

Cream Cup_Large ereamy white, slightly eup-shaped. White collar.

Diomedes-Purple and garnet on white ground, white collar.

Etoile de Montplaisier-Plum to mulberry red, extra long collar petals of white.

Leah-A splendid large collarette. Rich burgundy wine color.

Mme. E. Porriere-Deep blue, with white collar.

Pres. Vigor-Cherry red and magenta tones, with white collar.

Sov. de Chabanne-Ground color is lemon yellow, with coral red markings. The petals are lemon, tipped white.

Wm. Welsh-Clear light yellow.

Vyona-A new coloring in this type. White, heavily shaded rose pink. Sometimes comes single. About the prettiest of them all.

\section{GROWING OUR DAHLIAS IN EUROPE}

M. T. writes from "Ardfallen" Stanhope Rd., Craydon, Surrey, England. Last year you sent me 50 tubers, which were a very great success-please send me 50 more-all my friends who saw my Dahlias, went into raptures over them.

Mr. Edmund P. of Coliingwood, N. J., says-Dahlia tubers received in good condition, and they were so well packed that they could undoubtedly have been sent to Greenland without damage from frost. 


\section{Instructions in Planting}

By LESLIE E. DOOLITTLE

N. B.-These instructions should be read carefully, and followed closely in order to have the results come up to, or beyond expectations.

The Dahlia tuber, in the condition in which it reaches the customer, needs neither a severe soaking in water nor a strong stimulant in the way of a fertilizer, in planting. These two elements have been worked overtime in the planting of Dahlias, with often otherwise than the best of results. Speaking from experience, and with knowledge of the results in the different soils, my advice to the customer is the same rule as that which I follow. Too much early watering will, if the tuber survives the drowning process, create the action of the potash in the soil, which will cause wood growth, the plant growing tall and the blooms more or less inferior, and being an unnatural growth, the tubers, when lifted, will be found to be of mammoth size, with weakened crown, which will be found to decay readily and without apparent cause.

Manure coming in contact with the tuber, will cause scab, weaken the tuber, and often destroy it.

Plant therefore, in well worked soil, two and one-half to three feet apart, at a depth of five or six inches, in earth as free from fermenting vegetation and manure as possible. Give thern just enough water, when above ground, to keep them growing slowly. Apply manures and water in quantities, only after the plant starts to bud, and it will be found that you have saved the forcing quality for the blooms instead of its being expended upon stalk growth.

Up to the time the plant comes into bud it is greatly benefited by trimming off of the older foliage with a sharp knife, being careful not to trim off any of the future budding growth, my idea being that it is especially necessary, in order to have good blooms, that the foliage be kept clean, as it is through the pores of the plant that the oxygen is absorbed. By spraying with a sharp force of water from the garden hose, the plant can ordinarily be kept in a healthy condition, and this should be done at close intervals, in accordance with weather conditions.

Where chicken manure can be obtained I recommend its use, though barnyard manure is excellent. Feed the plant only after the eye, or sprout, has formed root feeders, it being remembered 
that the dormant tuber acts as a feeder only to the new sprout, and could not possibly absorb liquid to its advantage. Be careful not to use too great a percentage of nitrate of soda, as it will retard your blooms and make the stems very long, but weak. Phosphates are what are needed to produce good blooms, potash for wood growth and nitrates for a healthy foliage. I caution my customers against using too much fertilizer, but recommend working the soil a great deal.

Do not allow the blooms to seed, but cut all the old blooms, together with as much stem as possible. If allowed to seed the variety will fast deteriorate.

Manner of Use of Tools in Separating

Is Shown Here

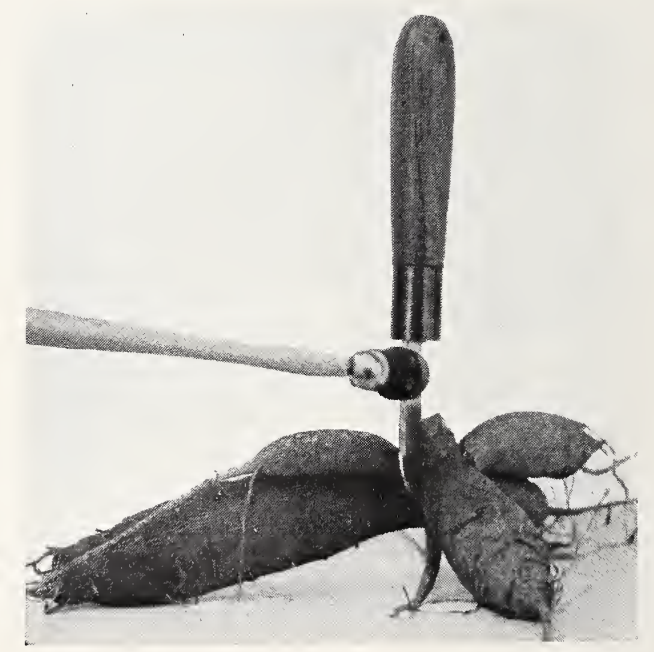

Follow these instructions as closely as possible, and write me of your results. I will always be pleased to hear from my trade who live at too great a distance to make me a call. Demonstrations of planting are made at my gardens. Manner of separation of tubers is shown; in fact, everything is done to assure success to the grower of my Dahlia tubers.

I wish to give another rule, also, as regards the fertilizer to be used. Three seasons past I hit upon the idea of working back to the soil that which has been taken out, so after saving all of my trimmings from the Dahlia plants, including old blooms, waste tubers, etc., from my previous crop, I made a huge compost pile of these, together with oak leaf mold and soil, and 
at planting time dug holes eighteen inches deep and about the same in diameter, and also put in two good shovelfuls of my compost mixed with more straight soil until the hole was filled within about eight inches of the surface of the garden bed, then a bit more straight soil, so that the tuber would not come in direct contact with the compost, then palnted in the position in which the tuber is shown in this cut, and covered the crown or top of the tuber with straight soil to a depth of from four to six inches. The results which were attained were quite the best yet, and not one bit of manure of any sort was used during the entire season. I used no manure in this case,

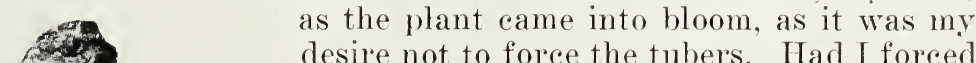
desire not to force the tubers. Had I forced the root system as the plants began to form buds I would, of course, have had even larger blooms than I plant, would have been the proper method of forcing for large blooms, but to force the plant too much means to do so at the expense of the tubers.

It is well to be a bit discreet about the amount of forcing given. In using the Dahlia plant compost you put into the soil just what the plant has consumed, and what it will consume again, so this, you will find is a well balanced Dahlia plant food.

After the plant is through blooming in the fall it is best to trim the plant in much the same manner as shown on next page. It will be noted that the stalk of the plant is cut above the last joint nearest the top of the plant. Having been cut at this height it will be seen that it avoids leaving a large opening in the stalk, as would have been the case had it been cut lower on the plant, which would have allowed rain water to stand in the stalk, and would be apt to start decay at the base of the old stalk, this being the vital point of the new crop of tubers, and is what we term the "crown'. It is here that the new eyes, or shoots, appear.

Send payment for order only-I prepay postage. 


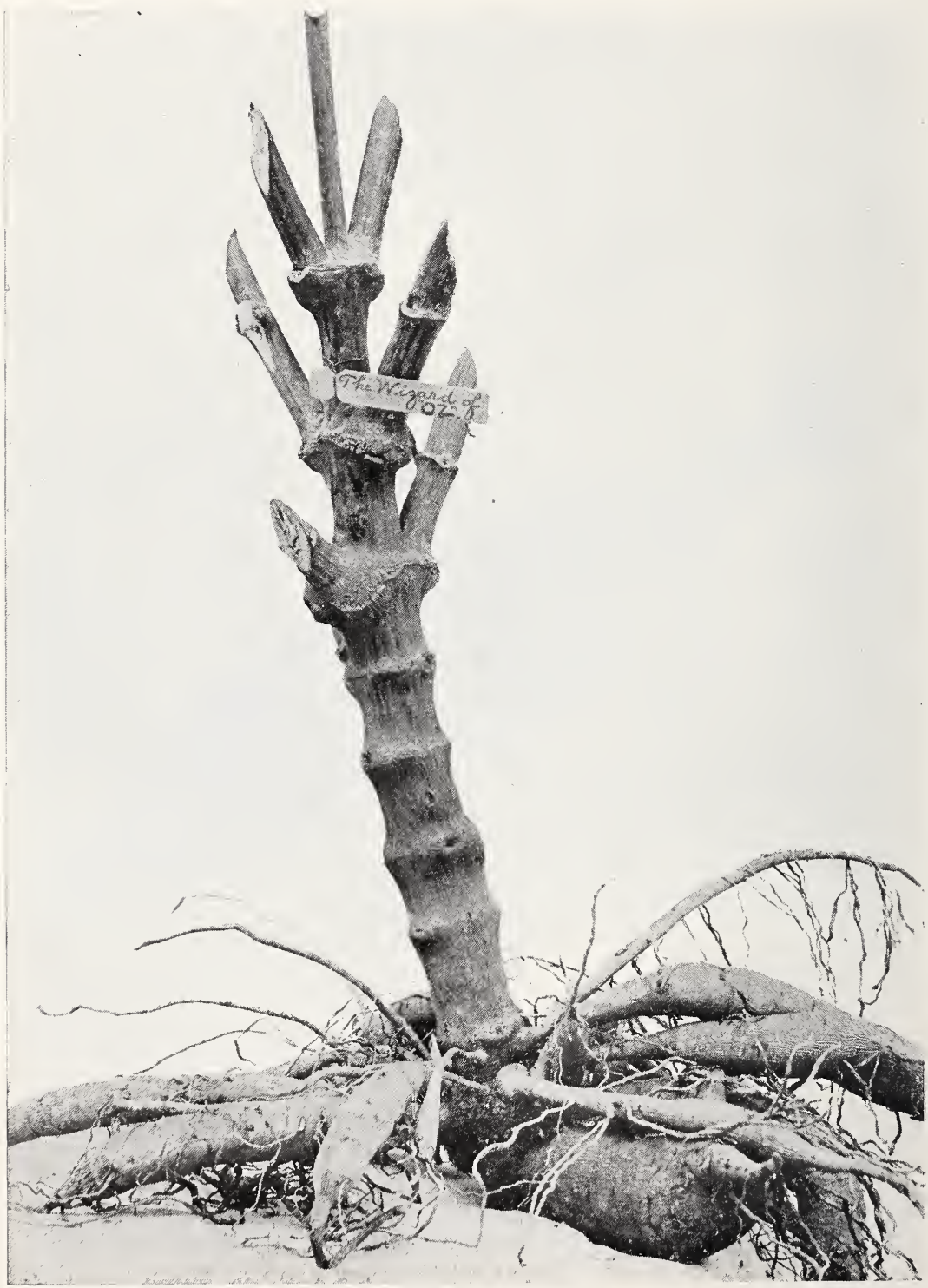

This shows the manner in which the stalk should be trimmed after the plant is through blooming 
The large tuber on the right of this clump of tubers, is what is termed the "mother" tuber, and should be destroyed at time of separating, as it is apt to decay another season, after being planted the second time. It will also be found that this old tuber does not multiply to any great extent, as the food values it contained, have been absorbed by the newer growth.

After trimming the plants in the manner indicated, leave the plant undisturbed for a few weeks, or until the stalks are thoroughly dried, which will be an indication that the tubers are quite

Necessary Tools to be

Used in the

Separation of Tubers

are Here Shown

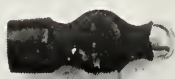

thoroughly matured, but not cured. We now reach the point where extreme care should be exercised. It would be well to loosen the entire clump, cutting all the feeders, or roots, at the extreme end of the tubers, and leave in the same spot in the garden with sufficient soil heaped about the clump to avoid its freezing. Leave in this condition for a few days, then lift the clump carefully so as not to break the necks of the tubers, place the clump upon a suitable rack, for washing, remove all the soil by means of a stream of water from the garden hose, and leave in the open air for a few hours only, to dry a bit, then place upon

We have customers in Brazil, in Peru, in Chili, in China. 
a bench or suitable table built to a proper height as to enable one to work to the best possible advantage in separating. The manner of separating is shown here, also the tools necessary to do good work.

After separating, the tubers should appear much the same as the single tuber shown on page 7 , all decay removed and broken ends carefully trimmed. Now place the tubers in an open airy situation for a few hours, in order that the cuts may become thoroughly dry, then pack away in sawdust or shavings, until planting out time. Labels with name of the variety being handled, should be constantly used in this work, to avoid getting the stock mixed.

In case the tubers shrivel too greatly, it is a sign that they have not been handled according to directions, but do not become disgusted or discouraged, but try again, as there is no mystery connected with Dahlia culture. I have found that there is only a little knack about it, after a person has good stock to work with. It is essential that the grower from whom you buy your stock, does not allow it to go to seed at random, in the fall. At this time the frosts appear, driving the sap downward toward the new tubers, and, apparently taking minute particles of coloring matter with it, to the new growth. When pollen has been carried from other, and stronger colored varieties, and the plant is allowed to seed in the fall, deterioration may be expected.

My prices are set to allow only a legitimate profit, and $\mathrm{my}$ goods are right, as any poor stock is destroyed.

Mr. L. E. Doolittle,

Los Angeles, Cal., Nov. 6, 1921.

Del Monte, Cal.

Dear Sir :

At the California Flower Show recently held at the Exposition Park we had a number of cut Dahlia bloom entries in competition.

It may interest you to know we entered "Earle Williams" for our best vase of one variety, 12 blooms, California origin, and won First prize.

$$
\text { Yours Very Truly C. F. G. }
$$

Mrs. F. H. F., of Trenton, N. J., writes: Your Dahlia, "The Screamer", was one of the most beautiful, "Vasanta", is one after my own heart, "Earle Williams', a beauty-had lovely flowers of it. "Maryan' had fine blooms, especially at Show time. 


\section{DAHLIA HISTORY}

The following is from "Garden Flowers in Color"- "Dahlias"-by George Gordon V. M. H., Past President of the National Dahlia Society of England, one of the best authorities on this flower, and you will find the book the most complete of its kind.

Although his history of the Dahlia in its relation to the garden does not extend over a period exceeding 123 years, it is necessary to go back nearly three centuries in quest of the first description and illustrations of the flower, whether the search might with profit be continued to a more remote period is doubtful. There is no evidence to justify the belief that there is an earlier record of the Dahlia than the one given by Francisco Hernandez, physician to Philip II of Spain, in his work on the plants and animals of New Spain, or Mexico, which was published in 1615 . Hernandez described the flower under the Mexican name of "Acoctii," and the account is of much interest from the fact that two forms-D. variabilis and $D$. crocata-are figured in connection therewith, and that both have single flowers. In a book that was based on the foregoing and published at Rome by Vitalis Mascardi in 1651, there is a figure of a Dahlia that, owing probably to indifferent drawing, leaves one in doubt as to whether the flower was double or single. If it is intended to represent a double bloom, there is nothing to show whether the doubling had been effected under natural conditions or within the boundaries of the garden. The probability is that the flower figured was single, and there is no other ground for assuming that the Dahila was undergoing modification in the direction of an increase in the number of florets at so early a period.

In the year 1789 the Dahlia was introduced into this country, but unfortunately the plants that were first raised failed to retain their vitality in the conditions to which they were subjected. In the course of that year Vincentes Cervantes, director of the Mexican Botanic Garden, sent seeds of the Dahlia to the Abbe Cavanilles, director of the Royal Gardens at Madrid. At that time the Marquis of Bute was the English Ambassador at the Spanish Court, and the Marchioness, who was greatly interested in floricultural matters, obtained some of these seeds and sent them home. From them plants were raised; but owing to their having been grown in a greenhouse, without probably an annual rest, it was not found possible to keep them alive more than two or three years. Nothing further was seen of the Dahlia in this country until 1802, when John Fraser, an enterprising nurseryman carrying on business in Sloane Square, obtained from Paris some seed of Dahlia coccinea, a now well-known, single form with rather small, brilliant scarlet flowers borne on long, rigid stems of a deep bronze-green hue. From these he raised plants that flowered in one of his greenhouses in the following year, and from one of the blooms a coloured plate was prepared and published in the Botanical Magazine, Tab. 762, a place being thus secured for the Dahlia in the botanical literature of this country. Ten years later the second edition of Aiton's Hortus Kewensis was published, and in this work two reputed species and three varieties were included.

Abbe Cavanilles would appear to have been successful in the raising and cultivation of his Dahlias. One of the plants raised from the Mexican seed produced semi-double flowers in 1790 , and in January of the following year was figured in his Icones et Descriptiones Plantarum, the publication of which was commenced in Madrid in 1791, as Dahlia pinnata, the early designation of the species now known as D. variabilis. 
Cavanilles dedicated the plant to M. Andre Dahl, a Swedish botanist of distinction, and the author of a work on the Linnaean system published in 1874. We have thus evidence that the doubling of the Dahlia in Europe commenced in the year in which it first flowered in Spain. The failures to grow the Dahlia when first introduced to this country and France were due to cultivators, regarding it is a tropical plant requiring much heat, whereas it has its home on the higher plateaux of Mexico, and thrives in comparatively low temperatures. Humboldt and Bonpland in their fanous explorations in Mexico, which commenced in 1799, found Dahlias growing wild in a prairie between Areo and Patzcuaro at an altitude of 5000 feet above the sea level.

In 1804, the year in which the illustration of Dahlia coccinea was published in the Botanical Magazine, a second supply of seed was received in this country from Madrid. This was sent by Lady Holland to M. Bounainte, librarian to Lord Holland at Holland House, Kensington, and he was successful in raising the three varieties coccinea, crocea, and purpurea. They all bloomed satisfactorily, and were figured in the botanical periodicals. At that period the light and elegant single flowers which are now so highly appreciated were not regarded as sufficient by the flower-loving public, and no sooner had the Dahlia made its way into gardens than strenuous endeavors were made by cultivators to obtain varieties with double flowers. During the first ten years or so of the nineteenth century the Dahlia made its way into several of the chief countries of the Continent of Europe, and was received with much favour.

By this time the Dahlia had become established in English gardens, and it rapidly increased in popular favour, whilst the increased demand for novelties induced raisers to work with even greater energy to provide new and improved varieties. Exhibitions multiplied in all parts of the United Kingdom, and thousands of blooms were annually shown during the period when the Dahlia was at the zenith of its popularity as aii exhibition flower, this period extending from 1820 to 1860 . The flowers that found favour with growers during the greater part of this period showed much diversity in form and colour, and were similar to the decorative varieties that were brought into prominence about 1870 . They were the presecursors of the type known as the show Dahlia, and until 1830 the blooms were smaller than those of the present day, and many of them had florets that were long and pointed and more or less cupped. After the next twenty years rapid progress was made in the development of the Dahlia along the lines laid down by the recognized authorities. The florets lost their points and became smooth and rounded, and so regularly arranged as to give the blooms an unbroken outline, which the height of the crown and the refinement of the flower materially increased. Concurrently with the development of the show Dahlias the fancy varieties were evolved. The difference between the two sections is merely a matter of colour, the show flowers being self coloured or tipped with a darker colour, while the fanciers are striped, or flawed, with a deeper colour on a light ground, or tipped with a lighter colour.

During the period from 1840 to 1860 , the show and fancy Dahlias were supplemented by the small-flowered varieties variously known as bouquet, lilliputian, and pom pon; the last name being now generally recognized. Their origin has long been a source of perplexity to those who are interested in the historical aspect of the Dahila, and one may search in vain for direct evidence upon this point. There is, however, no doubt 


\section{TO THE TRADE-}

We allow a trade discount of one third off the straight retail prices, as listed in this Catalogue. We make no exception in the newer introductions.

All Postage or Express charges to be paid by the Consignee, so please include sufficient amount to cover postage.

We make no extra charge for careful packing, but all goods are sent at the risk of the Buyer, especially so when freezing weather prevails at time of shipment. 

that they were of German origin, that they were raised in the district of which Koestritz is the center, and introduced to this country in the middle of the nineteenth century.

Of still greater importance in relation to the restoration of the Dahlia in popular favour was the introduction of Dahlia Yuarezzi, the first of the cactus Dahlias now so highly esteemed by flower lovers. This created much interest when first presented to public notice at one of the meetings of the Royal Horticultural Society held in the autumn of 1876 , by the late W. H. Cullingford. This Dahlia was received in the year 1872 by Mr. J. T. Van der Berg of Juxphaar near Utrecht, from a friend in Mexico. The case in which it was sent to Holland contained various kinds of bulbs, flower-roots, and seeds, and owing to the length of time it was on the journey the contents were received in an indifferent condition. The roots that were not wholly decayed were taken care of, and from a small tuber a growth was produced. Several plants were raised, and during the following summer they were grown with the other Dahlias in the open ground. When they came into flower the distinct and elegant form and the brilliant colour of the blooms at once attracted attention; and $\mathbf{M}$. Van der Berg, who had sent roots to a French firm in the autumn of 1873 , distributed it in 1874, having previously named it Yuarezii in honour of the then President of Mexico.

The cactus Dahlias have €njoyed a high degree of popularity, and there is every anticipation that they will for many years hence continue to increase in favour. The diversity in the form and colour of the cactus varieties prepared the flower-loving public for the new race of paeonyflowered varieties, remarkable for the extravagant form and attractive colours of their ilowers. These are said to have been introduced to this country in 1900 , but it was not until the autumn of 1905 that they were shown in London and at several of the continental exhibitions by Messrs. Copyn and Sons, by whom they were introduced to cultivation. They originated from the intercrossing of single and cactus varieties, and presumably those sorts remarkable for their robust habit and the large size of their flowers.

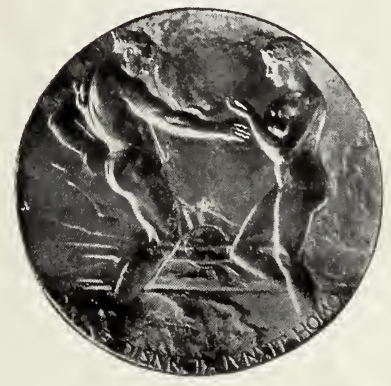

\section{Our Dahlias Won Highest Award Ever Offered}

\section{GOLD MEDAL}

For Best General Collection-Official Dahlia Show Panama-Pacific Exposition, San Francisco, 1915

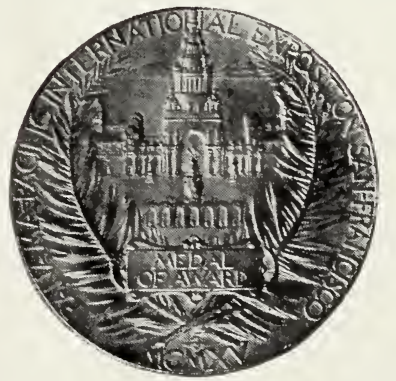




\section{OUR BUSINESS \\ Yesterday - Today - Tomorrow}

I BELIEVE in the sanctity of contracts as the foundation of business.

I BELIEVE that only chaos and business tragedy can result from disregarding obligations which we have taken on.

I BELIEVE anyone that accepts my order and acts on it does so through belief in the integrity of myself and my Organization.

I BELIEVE he is entitled to consider me honest and responsible, and that it's up to me to maintain his confidence.

I BELIEVE he has a right to depend upon me to carry out my contract.

I BELIEVE he has a right to expect that I will not accept cancellations of contracts from my customers to the extent of endangering my ability to carry out my contract with him.

I BELIEVE that normal business and prosperity can be attained by no other means than by one and all living up to our contracts.

\section{WE ARE DOING SO-}

WE SHALL continue to do so.

We are looking into the FUTURE. 